\title{
A Long-lasting Winter Haze Episode in Xiangyang, Central China: Pollution Characteristics, Chemical Composition, and Health Risk Assessment
}

\author{
Huimeng Jiang', Han Xiao ${ }^{1}$, He Song ${ }^{1}$, Jian Liu ${ }^{1}$, Tao Wang ${ }^{2}$, Hairong Cheng ${ }^{1 *}$, Zuwu Wang $^{1 * *}$ \\ ${ }^{1}$ School of Resource and Environmental Sciences, Wuhan University, Wuhan 430079, China \\ ${ }^{2}$ Xiangyang Environment Protection Monitoring Station, Xiangyang 441021, China
}

\begin{abstract}
This study investigated the characteristics and chemical composition of $\mathrm{PM}_{2.5}$ during a long-lasting winter haze episode (Jan. 13-24, 2018) in Xiangyang of central China. The average daily concentration of the $\mathrm{PM}_{2.5}$ equaled $169.29 \pm 56.98 \mu \mathrm{g} \mathrm{m}^{-3}$, with water-soluble inorganic ions (WSIIs), organic carbon (OC), elemental carbon (EC), and trace elements accounting for $111.45 \pm 44.62,20.74 \pm 6.79,6.48 \pm 1.79$, and $10.53 \pm 3.84 \mu \mathrm{g} \mathrm{m}^{-3}$, respectively. The OC/EC ratios indicated mixed contributions from intensive traffic emission and secondary formation, and the estimated concentrations for the primary organic carbon (POC) and the secondary organic carbon (SOC) increased with the level of pollution. POC dominated the OC during mild and moderate pollution, whereas SOC dominated it during severe pollution. A strong positive correlation was found between the enrichment factor $(\mathrm{EF})$ and geo-accumulation index $\left(\mathrm{I}_{\mathrm{Geo}}\right)$ values, which were used to assess the contamination level of $\mathrm{PM}_{2.5}$-bound metal(loid)s. A health risk assessment, which was conducted to examine the noncarcinogenic and carcinogenic risks of the $\mathrm{PM}_{2.5}$-bound metal(loid)s, found that $\mathrm{As}, \mathrm{Cr}, \mathrm{Pb}$, and $\mathrm{Sb}$ posed potential noncarcinogenic risks to both children and adults and that two of these elements, As and $\mathrm{Pb}$, also posed potential carcinogenic risks. The total non-carcinogenic and carcinogenic risks from the $\mathrm{PM}_{2.5}$-bound metal(loid)s were slightly higher for adults $\left(3.07 \times 10^{3}\right.$ and $\left.3.78 \times 10^{-3}\right)$ than children $\left(2.71 \times 10^{3}\right.$ and $\left.2.99 \times 10^{-3}\right)$ and depended on the concentrations of the metal(loid)s rather than the level of pollution. Thus, the public and the government should implement appropriate measures to mitigate the health risks posed by $\mathrm{PM}_{2.5}$-bound metal(loid)s during winter haze episodes in Xiangyang.
\end{abstract}

Keywords: $\mathrm{PM}_{2.5}$; Haze episode; Metal(loid)s; Winter; Health risk assessment.

\section{INTRODUCTION}

Fine particulate matter $\left(\mathrm{PM}_{2.5}\right)$ has attracted increased attention by the public and government over the past years, due to its significant impact on global climate change, atmospheric visibility degradation, cloud processes, and public health risk (Huang et al., 2014). $\mathrm{PM}_{2.5}$ is directly emitted from emission sources, including industrial process, coal-fired power plant, vehicle exhaust, agricultural biomass burning, crustal dust. It is also indirectly formed through gas-to-particle conversions of volatile organic compounds (VOCs) and gaseous precursors $\left(\mathrm{SO}_{2}, \mathrm{NO}_{x}\right.$ and $\mathrm{NH}_{3}$ ) (Liu et al., 2016a).

As the world's second largest economy, China has been

\footnotetext{
${ }^{*}$ Corresponding author.

Tel.: +86-027-68775543; Fax: +86-027-68778893

E-mail address: chenghr@whu.edu.cn

${ }^{* *}$ Corresponding author.

Tel.: +86-027-68775543; Fax: +86-027-68778893

E-mail address: zwwang@whu.edu.cn
}

facing air quality deterioration in recent years. A long-lasting severe haze event in 2013 significantly impacted the public; the event covered 17 provinces and autonomous regions and threatened the health of 600 million people due to exposure to $\mathrm{PM}_{2.5}$-bound metal(loid)s or other potentially toxic compounds (Liu et al., 2016a). Specifically, approximately 690 (490-890) premature deaths, 45,350 (21,640-57,860) acute bronchitis and 23,720 (17,090-29,710) asthma cases were caused by the $\mathrm{PM}_{2.5}$ concentrations during the severe haze event of January 2013 in Beijing area (Gao et al., 2015). In 2015, deaths from $\mathrm{PM}_{2.5}$ pollution accounted for $31.14 \%$ (approximately 2.62 million people) of all deaths in China (Xie et al., 2018). Studies have evaluated the pollution characteristics and chemical compositions of $\mathrm{PM}_{2.5}$ in Chengde (Qu et al., 2019), Shijiazhuang (Shen et al., 2019), Zhengzhou (Wang et al., 2019), Hefei (Xue et al., 2019a), Shanghai (Wei et al., 2019), Beijing (Shen et al., 2019), and Wuhan (Liu et al., 2016b). However, there have been no investigations of $\mathrm{PM}_{2.5}$ during winter haze episodes, and at different pollution levels for Xiangyang.

Xiangyang $\left(31^{\circ} 13^{\prime}-32^{\circ} 38^{\prime} \mathrm{N}, 110^{\circ} 45^{\prime}-113^{\circ} 47^{\prime} \mathrm{E}\right)$ occupies a $19,800 \mathrm{~km}^{2}$ area and has more than 6 million people. It lies in the northwest of Hubei Province and in the middle reaches 
of the Han River, and is approximately $300 \mathrm{~km}$ from Wuhan (the capital of Hubei Province). It has a typical subtropical monsoon climate with four distinct seasons and is an industrial city producing iron and steel, rutile, coal, and cars. The east, middle, and west of Xiangyang is surrounded by hills (20\%), humpy grounds (40\%) and mountains (40\%), respectively.

The Xiangyang Statistics Yearbook (http://tjj.xiangyang.gov. $\left.\mathrm{cn} / \mathrm{tjsj} / \mathrm{sjcx} / \mathrm{tjnb} / 201912 / \mathrm{t} 20191230 \_2001072 . s h t m l\right)$ indicates the gross domestic product (GDP) of Xiangyang reached USD 62.59 billion in 2019, and was composed of agriculture $(4.88 \%)$, industry $(51.50 \%)$ and other industries $(43.62 \%)$. This ranked second highest in Hubei Province. Xiangyang has more than 900,000 cars in 2018 , and there were $7114 \mathrm{Gg}$ of coal consumption for power plants and $551 \mathrm{Gg}$ of coal consumption for residential biofuel. These are all potential emission sources of $\mathrm{PM}_{2.5}$. Statistically, the percentage of average number of days with moderate or higher pollution in January from 2015 to 2018 was more than $60 \%$ in Xiangyang. This is a high $\mathrm{PM}_{2.5}$ level, with an average $\mathrm{PM}_{2.5}$ daily mass concentration of $140 \mu \mathrm{g} \mathrm{m}^{-3}$ (Fig. S1). This makes it urgent to study the pollution characteristics, chemical composition, and health risks of $\mathrm{PM}_{2.5}$ during haze events in Xiangyang, with the goal of providing policy advice for the government to control haze pollution.

In this study, $\mathrm{PM}_{2.5}$ samples were collected during a longlasting winter haze episode from Jan. 13-24, 2018, in Xiangyang. Study goals were as follows: (1) to analyze the pollution characteristics and chemical compositions of $\mathrm{PM}_{2.5}$, including water-soluble inorganic ions (WSIIs), carbonaceous species (organic carbon [OC] and elemental carbon [EC]) and trace elements (TEs); (2) to estimate the formations of primary organic carbon (POC) and secondary organic carbon (SOC); (3) to simultaneously report the enrichment degree and contamination level of $\mathrm{PM}_{2.5}$-bound metal(loid)s; and (4) to assess the potential human health risks, including noncarcinogenic and carcinogenic risk, caused by exposure to $\mathrm{PM}_{2.5}$-bound metal(loid)s in ambient air at four different pollution levels.

\section{MATERIALS AND METHODS}

\section{Field Sampling Campaign and Determination of PM 2.5 Concentration}

The sampling site (XY) was located at the Xiangyang Environmental Protection Monitoring Station (XYEPMS; $\left.32^{\circ} 01^{\prime} 09^{\prime \prime} \mathrm{N}, 112^{\circ} 09^{\prime} 18^{\prime \prime} \mathrm{E}\right)$, which is surrounded by a residential area, school, supermarket, hospital and highways. The site is a state-controlled, typical urban air sampling site in Xiangyang, central China (Fig. 1). On the roof of the XYEPMS (15 m height), forty-eight pairs of $\mathrm{PM}_{2.5}$ samples and one pair of field blank samples were collected on quartz fiber filters (QFFs; Whatman, UK) and Teflon filters (TFs; Munktell, Sweden). The QFFs were prebaked at $500^{\circ} \mathrm{C}$ for $6 \mathrm{~h}$ in a muffle furnace to remove any contaminants on the filters and the TFs were prepared at a constant temperature and relative humidity $\left(25 \pm 1^{\circ} \mathrm{C}, 50 \pm 5 \%\right)$ for $48 \mathrm{~h}$ in advance, respectively.

The samples on QFFs were used to analyze WSIIs and carbonaceous species. The samples on TFs were used to determine the concentration of $\mathrm{PM}_{2.5}$ and TEs. The particles were collected using a medium-volume sampler $\left(100 \mathrm{~L} \mathrm{~min}^{-1}\right.$; TH-150F; Wuhan Tianhong Instrument Co., Ltd., China). To track the haze bloom-decay process, sample collection tried to increase the number of $\mathrm{PM}_{2.5}$ samples classified at different pollution levels as much as possible. This prevented the stoppage of sampling due to excessive filter resistance caused by a haze episode. Samples were collected four times a day from 06:00-11:00 (5 h), 11:30-16:30 (5 h), 17:0022:00 (5 h), and 22:30-05:30 (7 h) the next day, from January 13-24, 2018. After sampling, all filters were folded, wrapped in aluminum foil, sealed in plastic bags, and stored in a refrigerator at $-18^{\circ} \mathrm{C}$ to prevent any loss of volatiles prior to analysis.

To determine the $\mathrm{PM}_{2.5}$ mass concentrations, the filters were weighed before and after the samples were collected using an electronic microbalance (Secura 125-1S; Sartorius Lab Instruments GmbH \& Co. KG, Göttingen, Germany). After being weighed, the filters were stored in the refrigerator at $-18^{\circ} \mathrm{C}$ prior to chemical analysis. Since the pollution

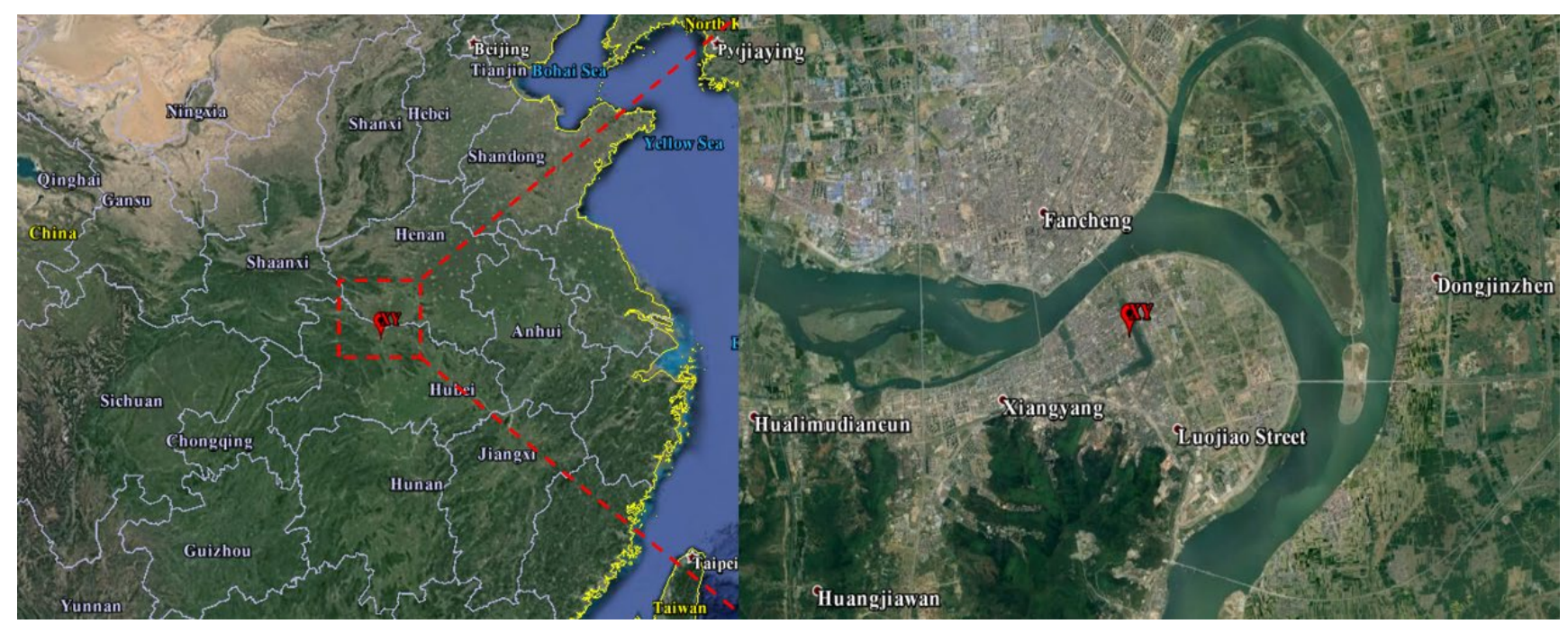

Fig. 1. The location of the sampling site (XY). 
characteristics, chemical compositions, formation reasons, and health risks of $\mathrm{PM}_{2.5}$ might be different at different pollution levels, sampling periods that experienced different $\mathrm{PM}_{2.5}$ mass concentrations were categorized at four pollution levels: mild pollution $\left(75 \mu \mathrm{g} \mathrm{m}^{-3}<\mathrm{PM}_{2.5} \leq 115 \mu \mathrm{g} \mathrm{m}^{-3}\right)$, moderate pollution $\left(115 \mu \mathrm{g} \mathrm{m}^{-3}<\mathrm{PM}_{2.5} \leq 150 \mu \mathrm{g} \mathrm{m}^{-3}\right)$, heavy pollution $\left(150 \mu \mathrm{g} \mathrm{m}^{-3}<\mathrm{PM}_{2.5} \leq 250 \mu \mathrm{g} \mathrm{m}^{-3}\right)$ and severe pollution $\left(\mathrm{PM}_{2.5}>250 \mu \mathrm{g} \mathrm{m}^{-3}\right)$ according to the National Ambient Air Quality Standard (GB 3095-2012; http://www.mee.gov.cn/ywgz/fgbz/bz/bzwb/dqhjbh/dqhjzl bz/201203/t20120302_224165.shtml) (Xie et al., 2019).

\section{Air-mass Back-trajectory Analysis}

The Hybrid Single-Particle Lagrangian Integrated Trajectory (HYSPLIT) model (v.4.8; https://www.arl.noaa.gov/hysplit/), provided by the U.S. National Oceanic and Atmospheric Administration, was used to calculate physical travel trajectories. Trajectories reaching the sampling site were calculated for a period extending $72 \mathrm{~h}$ into the past at a frequency of four times a day (00:00, 06:00, 12:00, 18:00 UTC). Each trajectory was estimated at $100 \mathrm{~m}$ above ground level and was cross-checked at $500 \mathrm{~m}$ and $1000 \mathrm{~m}$ above ground level. To determine the pollutant sources, three typical types of trajectories were classified using geographic information system (GIS) software (ArcGIS v.10.2) using a hierarchical clustering method because the corresponding percentage change in total spatial variance (TSV; \%) was the smallest one as three clusters were combined (Table S1).

\section{Chemical Analysis}

The analysis procedure of WSIIs, carbonaceous species and TEs was discussed in our previous study (Zhang et al., 2014; Lyu et al., 2015; Zhang et al., 2015). Briefly, a punch $\left(3.14 \mathrm{~cm}^{2}\right)$ of QFFs was extracted using $15 \mathrm{~mL}$ of Milli-Q water $(18.25 \mathrm{M} \Omega \mathrm{cm})$ and was sonicated for $45 \mathrm{~min}$ in an ultrasonic ice-water bath. The water extracts were filtered through a $0.22 \mathrm{~mm}$ hydrophilic filter and were then stored in a pre-cleaned centrifugal tube for samples analysis. Five cations $\left(\mathrm{Na}^{+}, \mathrm{NH}_{4}^{+}, \mathrm{K}^{+}, \mathrm{Mg}^{2+}\right.$ and $\left.\mathrm{Ca}^{2+}\right)$ and four anions $\left(\mathrm{F}^{-}, \mathrm{Cl}^{-}, \mathrm{NO}_{3}{ }^{-}\right.$ and $\mathrm{SO}_{4}{ }^{2-}$ ) were analyzed using ion chromatography (883 Basic IC plus; Metrohm, Switzerland). Before a targeted sample analysis, standard solution (ANPEL Laboratory Technologies Inc., China) and blank test were performed, and the correlation coefficients of standard samples exceeded 0.999. The method detection limits of $\mathrm{F}^{-}, \mathrm{Cl}^{-}, \mathrm{NO}_{3}^{-}, \mathrm{SO}_{4}{ }^{2-}, \mathrm{Na}^{+}$, $\mathrm{NH}_{4}^{+}, \mathrm{K}^{+}, \mathrm{Ca}^{2+}$ and $\mathrm{Mg}^{2+}$ were $0.010,0.012,0.027,0.030$, $0.019,0.020,0.025,0.037$ and $0.020 \mu \mathrm{g} \mathrm{m}^{-3}$, respectively.

To assess the carbonaceous species, OC and EC were analyzed using a thermal/optical reflectance carbon analyzer (DRI 2001 A; Desert Research Institute, USA). Briefly, a punch $\left(0.518 \mathrm{~cm}^{2}\right)$ of QFFs were heated stepwise in the oven at $140^{\circ} \mathrm{C}(\mathrm{OC} 1), 280^{\circ} \mathrm{C}(\mathrm{OC} 2), 480^{\circ} \mathrm{C}(\mathrm{OC} 3)$ and $580^{\circ} \mathrm{C}(\mathrm{OC} 4)$ for $150 \mathrm{~s}$ at each stage in a pure $\mathrm{He}$ gas atmosphere for $\mathrm{OC}$ volatilization and $580^{\circ} \mathrm{C}(\mathrm{E} 1), 740^{\circ} \mathrm{C}(\mathrm{E} 2)$ and $840^{\circ} \mathrm{C}(\mathrm{E} 3)$ for $150 \mathrm{~s}$ at each stage in a $2 \% \mathrm{O}_{2} / 98 \% \mathrm{He}$ atmosphere for EC oxidation. Pyrolyzed organic carbon (OPC) was produced in the inert atmosphere, decreasing the reflected light to correct for charred $\mathrm{OC}$ ( $\mathrm{Yu}$ et al., 2002). According to the Interagency Monitoring of Protected Visual Environments
$(\mathrm{IMPROVE})$ A A protocol, $\mathrm{OC}=\mathrm{OC} 1+\mathrm{OC} 2+\mathrm{OC} 3+\mathrm{OC} 4+$ $\mathrm{OPC}$ and $\mathrm{EC}=\mathrm{EC} 1+\mathrm{EC} 2+\mathrm{EC} 3-\mathrm{OPC}$. Replicate analyses were performed on $10 \%$ of the total samples, yielding differences within $3.95 \%$ for OC and $2.53 \%$ for EC. Standard concentrations of $\mathrm{CH}_{4} / \mathrm{CO}_{2}$ mixed gases were used to calibrate the analyzer in each day before and after the sample analysis.

To assess TEs, TFs were digested using an acid mixture

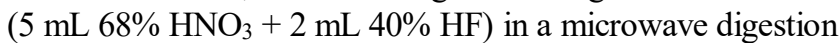
system. Twenty-five elements (Li, Be, Al, Si, V, Cr, Mn, Co, $\mathrm{Ni}, \mathrm{Cu}, \mathrm{Zn}, \mathrm{As}, \mathrm{Se}, \mathrm{Sr}, \mathrm{Mo}, \mathrm{Ag}, \mathrm{Cd}, \mathrm{Sn}, \mathrm{Sb}, \mathrm{Ba}, \mathrm{Tl}, \mathrm{Pb}, \mathrm{Bi}$, $\mathrm{Th}$ and $\mathrm{U}$ ) in solution were measured using inductively coupled plasma mass spectrometry (ICP-MS; NexION 350D; PerkinElmer, USA). The relative standard deviations between real values of soil national standard materials (SigmaAldrich, USA) were calculated, with results ranging from $0.10-18.00 \%$. The detection limits ranged from $0.00001-$ $0.0005 \mu \mathrm{g} \mathrm{L}^{-1}$ for trace elements. All reported data of WSIIs, carbonaceous species, and trace elements were corrected by the filter blank results.

\section{Contamination Level Assessment \\ Enrichment Factor}

To determine whether $\mathrm{PM}_{2.5}$-bound metal(loid)s found in greater abundance in ambient air originated from the earth's crust, the enrichment factor (EF) was used to assess the degree of enrichment of metal(loid)s in $\mathrm{PM}_{2.5}$ samples using Eq. (1) (Zhang et al., 2019).

$$
E F=\frac{\left(C_{i} / C_{r e f}\right)_{\text {Aerosol }}}{\left(C_{i} / C_{r e f}\right)_{\text {Crust }}}
$$

In this expression, $\left(C_{i} / C_{\text {ref }}\right)_{\text {Aerosol }}$ and $\left(C_{i} / C_{\text {ref }}\right)_{\text {Crust }}$ represent the ratio of the concentration of metal $i$ to the concentration of a reference metal in the aerosol samples and earth crust, respectively. $\mathrm{Fe}, \mathrm{Al}$, and $\mathrm{Si}$ are generally used as reference metal(loid)s. Al was selected as the reference metal for this study, because it is stable in the earth crust and is not easily affected by human activities. In this study, the metal concentrations in the earth crust were adopted from "The Background Values of Elements in Chinese Soil" in Hubei Province. The EF values between 2-10 indicated the important mixed impacts of crustal sources and anthropogenic emissions. Values exceeding 10 indicated that the anthropogenic emissions were the main source of metal(loid)s in ambient air (Dehghani et al., 2017).

\section{Geo-accumulation Index}

To compare the present concentration of metal(loid)s in $\mathrm{PM}_{2.5}$ samples with the concentration in the earth's crust, the geo-accumulation index $\left(\mathrm{I}_{\mathrm{Geo}}\right)$ was used to evaluate the contamination levels for metal(loid)s. The $\mathrm{I}_{\mathrm{Geo}}$ values were calculated using Eq. (2) (Zhang et al., 2019).

$$
I_{\text {Geo }}=\log _{2} \frac{C_{\text {iAerosol }}}{\left(1.5 \times C_{i \text { Crust }}\right)}
$$

In this equation, $C_{\text {iAerosol }}$ and $C_{i C r u s t}$ represent the 
concentration of metal $i$ in aerosol samples and the earth crust, respectively. The constant 1.5 allowed us to verify the natural fluctuations of a specific substance in the environment; very small anthropogenic influences were found. The $\mathrm{I}_{\mathrm{Geo}}$ values for $\mathrm{PM}_{2.5}$-bound metal(loid)s have been typically classified as uncontaminated $\left(\mathrm{I}_{\mathrm{Geo}} \leq 0\right)$, uncontaminated to moderately contaminated $\left(0<\mathrm{I}_{\mathrm{Geo}} \leq 1\right)$, moderately contaminated $\left(1<\mathrm{I}_{\mathrm{Geo}} \leq 2\right)$, moderately to heavily contaminated $\left(2<\mathrm{I}_{\mathrm{Geo}} \leq 3\right)$, heavily contaminated (3 $\left.<\mathrm{I}_{\mathrm{Geo}} \leq 4\right)$, heavily to extremely contaminated $\left(4<\mathrm{I}_{\mathrm{Geo}} \leq 5\right)$ and extremely contaminated $\left(\mathrm{I}_{\mathrm{Geo}}>5\right)\left(\mathrm{Li}\right.$ et al., 2019). $\mathrm{I}_{\mathrm{Geo}}$ values higher than 1 may indicate the influence of anthropogenic emissions.

\section{Human Exposure and Health Risk Assessment \\ Human Exposure Dose}

Potentially adverse human health risks, including noncarcinogenic and carcinogenic risks, can be caused by exposure to $\mathrm{PM}_{2.5}$-bound metal(loid)s in ambient air. Potential exposure can occur through three different pathways: ingestion, inhalation, and dermal contact. Human exposure was defined in terms of average daily exposure dose (ADED) of each metal and was then computed individually for each metal and each exposure pathways. ADED values were calculated through three exposure pathways, ingestion $\left(A D E D_{\text {Ing }}\right)$, inhalation $\left(A D E D_{\text {Inh }}\right)$, and dermal contact $\left(A D E D_{D e r}\right)$, using Eqs. (3)-(5).

$$
\begin{aligned}
& A D E D_{\text {Ing }}=C_{i} \times \frac{R_{\text {Ing }} \times E F \times E D}{B W \times A T} \times C F \\
& A D E D_{\text {Inh }}=C_{i} \times \frac{R_{\text {Inh }} \times E F \times E D}{B W \times A T \times P E F} \\
& A D E D_{\text {Der }}=C_{i} \times \frac{S A \times A F \times A B S \times E F \times E D}{B W \times A T} \times C F
\end{aligned}
$$

In this expression, $C_{i}$ was the concentration of metal(loid)s $i$ in $\mathrm{PM}_{2.5}\left(\mathrm{mg} \mathrm{kg}{ }^{-1}\right)$. In particular, the $\mathrm{Cr}$ concentration was calculated as one-seventh of the total $\mathrm{Cr}$ because only $\mathrm{Cr}(\mathrm{VI})$ was carcinogenic, while $\mathrm{Cr}(\mathrm{III})$ was not (Massey et al., 2013). The variable $R_{\text {Ing }}$ was the ingestion rate; $R_{I n h}$ was the inhalation rate; $\mathrm{ABS}$ was the dermal absorption factor; $E F$ was the exposure frequency; $E D$ was the exposure duration; $B W$ is the body weight; $A T$ was the averaging time; $P E F$ was the particle emission factor; $S A$ was the skin surface area in contact with air; $A F$ was the adherence factor for airborne particulates to skin; and CF was the conversion factor. Table S1 lists these variables (U.S. EPA, 2011; Ferreira-Baptista and De Miguel, 2005; Hu et al., 2012; Li et al., 2013).

\section{Non-carcinogenic risk}

The non-carcinogenic risks due to exposure to $\mathrm{PM}_{2.5}$ bound metal(loid)s (As, Cd, Cr(III), Co, Cu, Mn, Ni, Zn, Pb, $\mathrm{Ag}, \mathrm{Al}, \mathrm{Ba}, \mathrm{Mo}, \mathrm{Sb}, \mathrm{Sr}, \mathrm{U}$ and $\mathrm{V}$ ) were evaluated using the hazard quotient (HQ) and hazard index (HI). The HQ values are calculated by dividing ADED into a specific reference dose $(R f D)$. The total HI (THI) values indicated the mixed non-carcinogenic risk due to exposure to an individual metal and multiple metal(loid)s of three pathways in ambient air, respectively. The total non-carcinogenic risks through ingestion, inhalation, and dermal contact were estimated using Eqs. (6) and (7).

$$
H Q_{i}=\frac{A D E D_{i}}{R f D_{i}}
$$

$T H I=\sum H Q_{i}$

If the HI values were less than 1 , there was no significant non-carcinogenic risk; otherwise, there may be a noncarcinogenic risk with respect to human health.

\section{Carcinogenic Risk}

The carcinogenic risks (CRs) due to exposure to $\mathrm{PM}_{2.5}$ bound metal(loid)s (As, Cd, Co, Cr(VI), Ni and Pb) (U.S. EPA, 2011; Massey et al., 2013; IARC, 2020) were equals to ADED multiplied by a specific slope factor (SF). The CR and total carcinogenic risk (TCR) indicated the mixed carcinogenic risk due to exposure to an individual metal and multiple metal(loid)s of three pathways in ambient air, respectively. The CRs through ingestion, inhalation, and dermal contact, were estimated using Eqs. (8) and (9).

$$
\begin{aligned}
& C R_{i}=A D E D_{i} \times S F_{i} \\
& T C R=\sum C R_{i}
\end{aligned}
$$

Usually, a CR and TCR within the range of $1 \times 10^{-6}$ to 1 $\times 10^{-4}$ is acceptable, meaning that the metal(loid)s in ambient air likely does not have a carcinogenic risk for human health. The carcinogenic risk is categorized as very low $\left(\mathrm{CR} \leq 1 \times 10^{-6}\right)$, low $\left(1 \times 10^{-6} \leq \mathrm{CR}<1 \times 10^{-4}\right)$, moderate $\left(1 \times 10^{-4} \leq \mathrm{CR}<1 \times 10^{-3}\right)$, high $\left(1 \times 10^{-3} \leq \mathrm{CR}<\right.$ $\left.1 \times 10^{-1}\right)$, and very high $\left(\mathrm{CR} \geq 1 \times 10^{-1}\right)$ for human life (Roy et al., 2019).

\section{RESULTS AND DISCUSSION}

\section{General PM2.5 Mass Concentration and Pollution Characteristic}

Fig. 2 presents the mass concentrations of $\mathrm{PM}_{2.5}$, WSIIs, carbonaceous species, and trace elements in samples collected from Jan. 13-24, 2018. During this sampling period, Xiangyang had experienced a $12 \mathrm{~d}$ haze episode, with average daily $\mathrm{PM}_{2.5}$, WSIIs, OC, EC and TE concentrations of $169.29 \pm 56.98,111.45 \pm 44.62,20.74 \pm 6.79,6.48 \pm 1.79$ and $10.53 \pm 3.84 \mu \mathrm{g} \mathrm{m}^{-3}$, respectively. The average $\mathrm{PM}_{2.5}$ concentrations were 2.26-fold higher compared to the secondary standard $\left(75 \mu \mathrm{g} \mathrm{m}^{-3}\right)$ of the National Ambient Air Quality Standard. There were $8 \mathrm{~d}$ with pollution at heavy levels or above, and the proportion of moderate or greater pollution was $85.42 \%$, with a high pollution level in winter. The $\mathrm{PM}_{2.5}$ concentration during severe pollution (306.92 \pm $36.26 \mu \mathrm{g} \mathrm{m}^{-3}$ ) was approximately 2-3 times the level when 


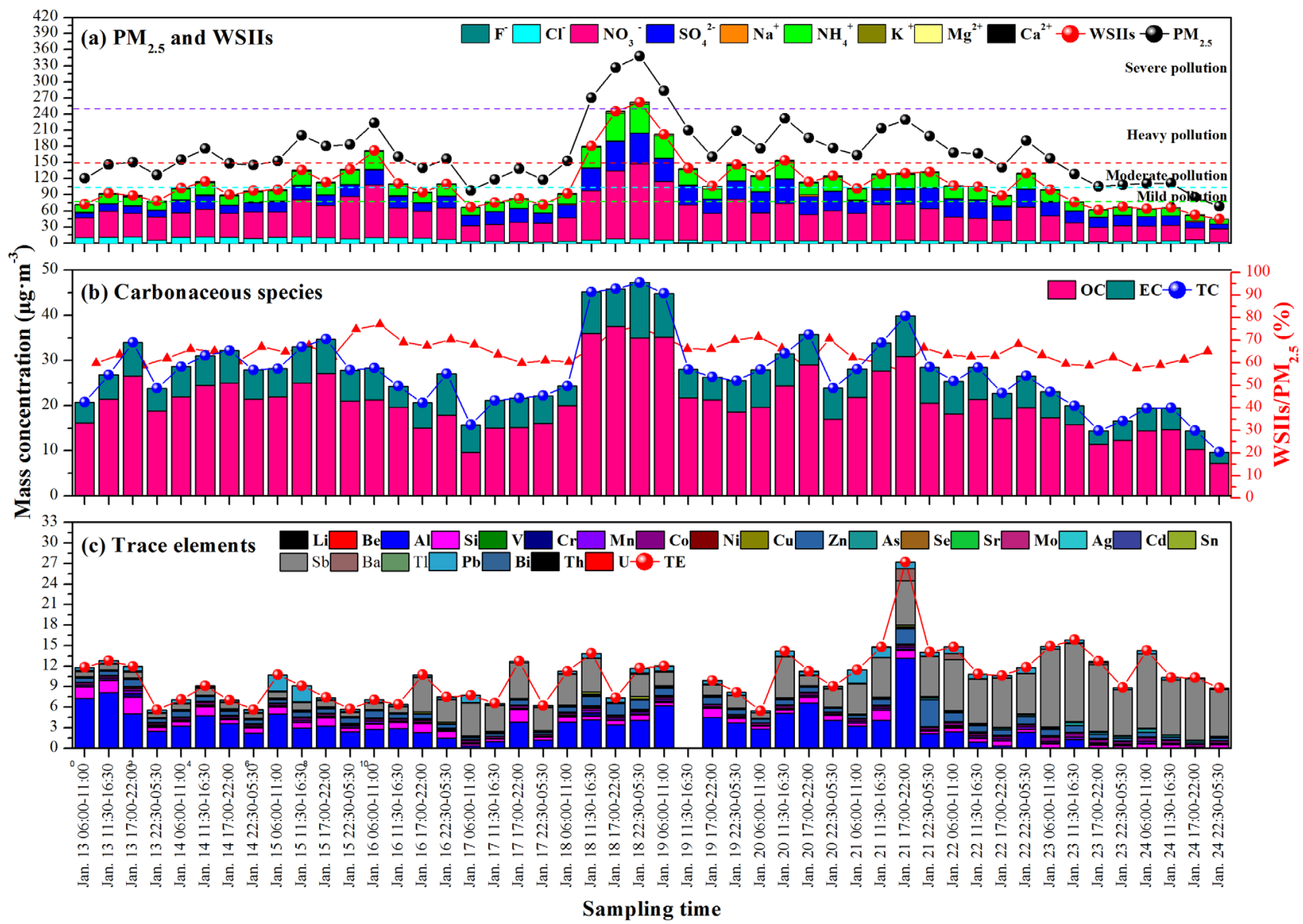

Fig. 2. The mass concentrations of (a) $\mathrm{PM}_{2.5}$ and WSIIs, (b) carbonaceous species, and (c) trace elements from Jan. 13-24, 2018. (The green, cyan, red, and violet dash line means mild pollution $\left(75 \mu \mathrm{g} \mathrm{m}^{-3}<\mathrm{PM}_{2.5} \leq 115 \mu \mathrm{g} \mathrm{m}^{-3}\right)$, moderate pollution $\left(115 \mu \mathrm{g} \mathrm{m}^{-3}<\mathrm{PM}_{2.5} \leq 150 \mu \mathrm{g} \mathrm{m}^{-3}\right)$, heavy pollution $\left(150 \mu \mathrm{g} \mathrm{m}^{-3}<\mathrm{PM}_{2.5} \leq 250 \mu \mathrm{g} \mathrm{m}^{-3}\right)$ and severe pollution $\left(\mathrm{PM}_{2.5}>\right.$ $250 \mu \mathrm{g} \mathrm{m}^{-3}$ ), respectively.)

there was mild pollution $\left(103.27 \pm 10.06 \mu \mathrm{g} \mathrm{m}^{-3}\right)$, moderate pollution $\left(113.64 \pm 11.56 \mu \mathrm{g} \mathrm{m}^{-3}\right)$, and heavy pollution $\left(182.31 \pm 25.59 \mu \mathrm{g} \mathrm{m}^{-3}\right)$.

The $\mathrm{PM}_{2.5}$ concentration reached the highest level from Jan. 18-19 during severe pollution. This may have been caused by air masses from the NNW-NE (Cluster 3) direction, accounting for $14 \%$ of all trajectories. These air masses originated from Inner Mongolia, passed through Hebei and Shanxi Province, turned a corner in Shandong Province, and finally approached the sampling site through Henan Province with higher transport speeds $\left(4.74 \mathrm{~m} \mathrm{~s}^{-1}\right)$ than the average wind speed $\left(3.02 \mathrm{~m} \mathrm{~s}^{-1}\right)$ obtained from Hubei Meteorological Service during the whole winter haze episode (Fig. 3). The $\mathrm{PM}_{2.5}$ and its components had higher concentrations than other directions (Table S2). This may be influenced by Hebei, Shanxi, and Henan Province, due to significant amounts of polluted air carried down from these high-pollution areas. Shanxi Province has the largest explored coal reserves and abundant mineral resources in China, with many industries, including power plants and steel works. This is also the case for Hebei and Henan Province.

In contrast, the $\mathrm{PM}_{2.5}$ concentration reached the lowest level on Jan. 23-24 during mild pollution. This level may have been affected by air masses from the NW-NE (Cluster 2) direction, accounting for $24 \%$ of all trajectories. This air mass initiated in Gansu Province, passed through Shaanxi and Hebei Province, turned a corner in Henan Province, and finally approached the sampling site through Henan Province with similar transport speeds $\left(2.72 \mathrm{~m} \mathrm{~s}^{-1}\right)$ to the average wind speed. During this period, the wet deposition from weather, such as snow and rain, dominated Xiangyang, resulting in low pollutant concentrations at XY site.

A total of $62 \%$ of the air masses came from NW-SW (Cluster 1) direction; this pattern prevailed from Jan. 13-17 and Jan. 19-22, 2018, during moderate and heavy pollution. The pattern originated from Henan Province, turned a corner in Hubei Province, and then approached the sampling site with relatively lower transport speeds $\left(2.45 \mathrm{~m} \mathrm{~s}^{-1}\right)$ than the average wind speed. The $\mathrm{PM}_{2.5}$ and associated species were present at high concentrations; this did not support pollutant dispersion due to unfavorable meteorological conditions and local emissions dominating Xiangyang during this period.

When compared to other cities around the world (Table S3), the $\mathrm{PM}_{2.5}$ concentration in Xiangyang was comparable to the concentration in Wuhan $\left(159.5 \mu \mathrm{g} \mathrm{m}^{-3}\right)$ in 2013 . The level was significantly higher compared to most cities in China, 


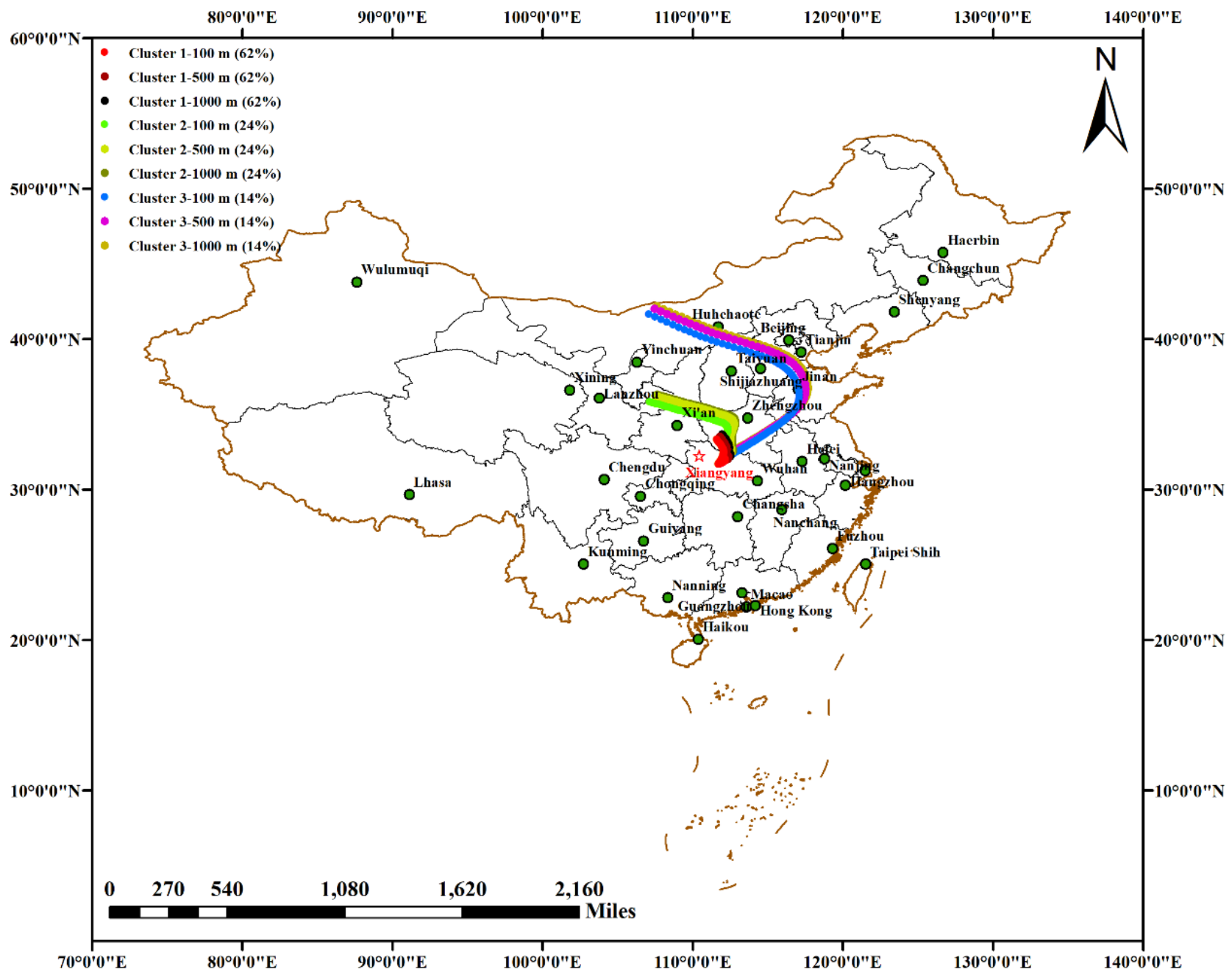

Fig. 3. Three typical air-mass back trajectories estimated at $100 \mathrm{~m}, 500 \mathrm{~m}$, and $1000 \mathrm{~m}$ above ground level at XY during Jan. 13-24, 2018.

including Beijing $\left(117.0 \mu \mathrm{g} \mathrm{m}^{-3}\right)$ (Shen et al., 2019), Tianjin $\left(124.0 \mu \mathrm{g} \mathrm{m}^{-3}\right)$ (Shen et al., 2019), Guilin $\left(144.0 \mu \mathrm{g} \mathrm{m}^{-3}\right)$ (Zhong et al., 2019), Xinxiang (109.9 $\mathrm{g} \mathrm{m}^{-3}$ ) (Liu et al., 2019), Chengdu (113.2 $\mu \mathrm{g} \mathrm{m}^{-3}$ ) (Qu et al., 2019), Shanghai $\left(92.9 \mu \mathrm{g} \mathrm{m}^{-3}\right)$ (Wei et al., 2019), and Hefei $\left(81.0 \mu \mathrm{g} \mathrm{m}^{-3}\right.$ ) (Xue et al., 2019b). The level was also higher than cities in other countries, for example, Riyadh, Saudi Arabia $\left(71.9 \mu \mathrm{g} \mathrm{m}^{-3}\right)$ (Modaihsh et al., 2015); Zonguldak, Turkey $\left(37.3 \mu \mathrm{g} \mathrm{m}^{-3}\right.$ ) (Akyüz and Çabuk, 2009); and Iasi, Romania $\left(23.4 \mu \mathrm{g} \mathrm{m}^{-3}\right.$ ) (Galon-Negru et al., 2018). The level was significantly lower than the levels in Zhengzhou $\left(188.2 \mu \mathrm{g} \mathrm{m}^{-3}\right.$ ) (Wang et al., 2019); Shijiazhuang (215.0 $\left.\mu \mathrm{g} \mathrm{m}^{-3}\right)$ (Shen et al., 2019); and Delhi, India $\left(293.1 \mathrm{\mu g} \mathrm{m}^{-3}\right)$ (Khanna et al., 2018).

\section{Chemical Composition}

Water-soluble Inorganic Ions

Fig. 4(a) shows the mass concentration of WSIIs and the ratios of secondary inorganic aerosol (SNA) to WSIIs and WSIIs to $\mathrm{PM}_{2.5}$ at four pollution levels. The average ratios of WSIIs to $\mathrm{PM}_{2.5}$ (WSIIs/PM $/ .5$ ) were $64.91 \pm 5.04 \%$ (56.66$76.99 \%$ ), explaining the most components of $\mathrm{PM}_{2.5}$ (Fig. 4(a)). In addition, $\mathrm{SO}_{4}{ }^{2-}, \mathrm{NO}_{3}{ }^{-}$, and $\mathrm{NH}_{4}{ }^{+}$dominated the WSIIs, at a proportion of $91.62 \pm 3.90 \%$. The average $\mathrm{NO}_{3}{ }^{-}$concentration $\left(54.38 \pm 25.09 \mu \mathrm{g} \mathrm{m}^{-3}\right)$ was approximately 2 times higher compared to $\mathrm{SO}_{4}{ }^{2-}$ concentration $\left(25.85 \pm 10.86 \mu \mathrm{g} \mathrm{m}^{-3}\right)$. The $\mathrm{NO}_{2}$ concentration $\left(54.89 \mu \mathrm{g} \mathrm{m}^{-3}\right)$ from emission sources was significantly higher compared to the $\mathrm{SO}_{2}$ concentrations $\left(23.86 \mu \mathrm{g} \mathrm{m}^{-3}\right)$. Moreover, a high temperature, high relative humidity, and high radiation were more favorable for the formation of $\mathrm{SO}_{4}{ }^{2-}$ (Yang et al., 2018). Hence, lower temperature and radiation levels may not support the formation of $\mathrm{SO}_{4}{ }^{2-}$ during winter in this city.

Almost all the WSIIs concentrations increased as the pollution level increased: mild pollution $\left(63.01 \pm 5.57 \mu \mathrm{g} \mathrm{m}^{-3}\right)$ $<$ moderate pollution $\left(83.60 \pm 9.38 \mu \mathrm{g} \mathrm{m}^{-3}\right)<$ heavy pollution $\left(119.91 \pm 20.59 \mu \mathrm{g} \mathrm{m}^{-3}\right)<$ severe pollution $(222.37$ $\pm 37.69 \mu \mathrm{g} \mathrm{m}^{-3}$ ). The SNA-to-WSIIs ratio (SNA/WSIIs) and WSIIs-to-PM $\mathrm{P}_{2.5}$ ratio increased as the pollution levels increased. This indicated an intensification in the secondary formation of winter haze episodes in Xiangyang.

The average ratios of anions to cations at the four pollution levels of mild, moderate, heavy, and severe were $1.06 \pm 0.02$, $1.13 \pm 0.06,1.11 \pm 0.06$ and $1.09 \pm 0.01$, respectively (Fig. 4(b)). The average ratios of anions to cations approached 1 , 

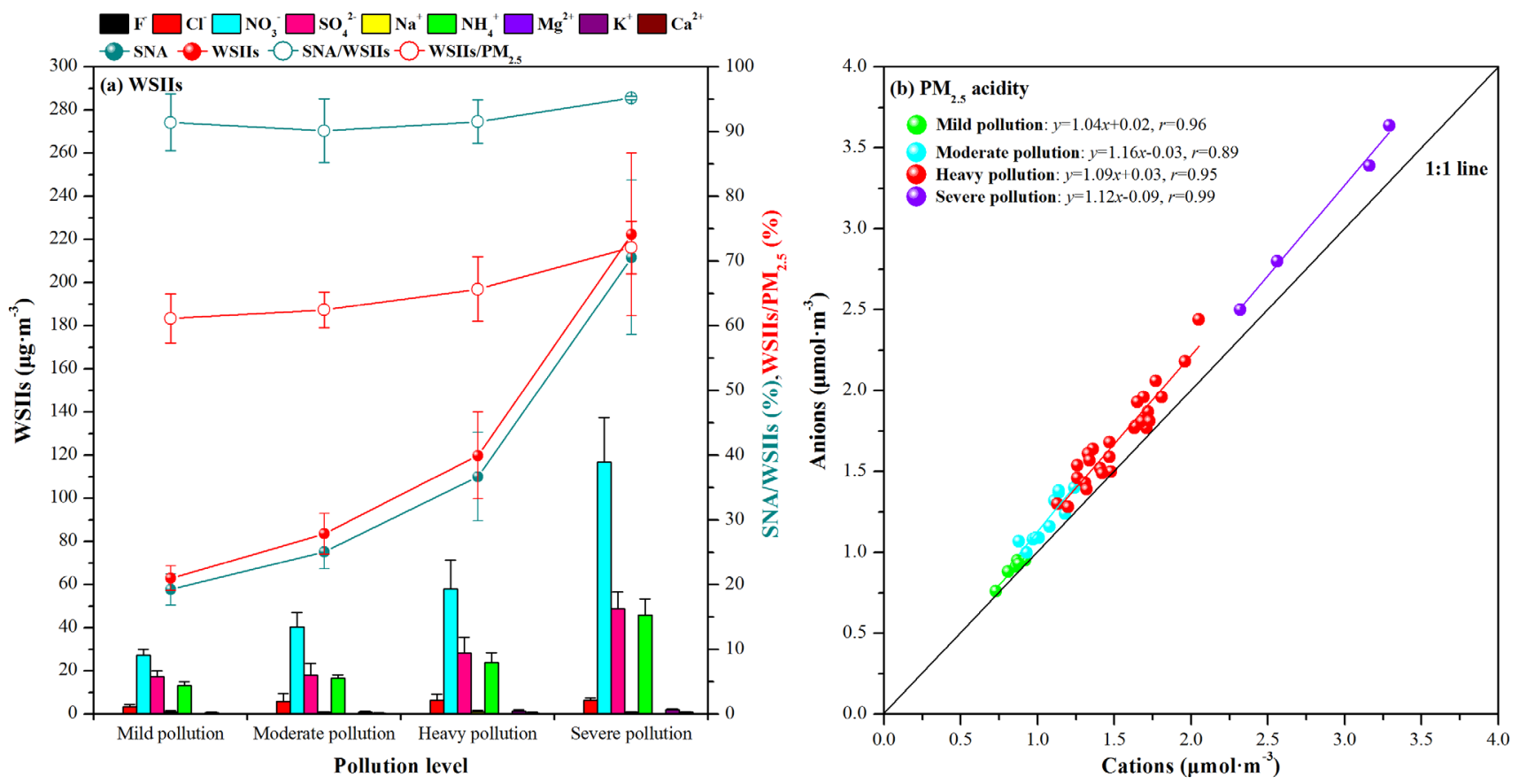

Fig. 4. (a) WSIIs concentrations and (b) $\mathrm{PM}_{2.5}$ acidity at the four pollution levels.

with strong positive correlations $(r=0.96,0.89,0.95$ and $0.99, p<0.05$, respectively) between anions and cations. This indicated these ions were the important alkaline and acidic species in the $\mathrm{PM}_{2.5}$ (Wang et al., 2005). The ratio of anions to cations is also an effective indicator to study aerosol acidity (Cheng et al., 2014); that ratio exceeded 1 at the four pollution levels, indicating that the aerosols were acidic during the haze episodes.

The $\mathrm{NO}_{3}{ }^{-} / \mathrm{SO}_{4}{ }^{2-}$ ratio is generally considered a good indicator to assess the relative contribution of sulfur and nitrogen between stationary sources (e.g., power plant) and mobile sources (e.g., vehicle exhaust) in the atmospheric environment (Yin et al., 2014). The average $\mathrm{NO}_{3}{ }^{-} / \mathrm{SO}_{4}{ }^{2-}$ values were $1.61 \pm 0.16,2.48 \pm 0.94,2.18 \pm 0.70$ and $2.39 \pm$ 0.54 at mild, moderate, heavy, and severe pollution level, respectively. The $\mathrm{NO}_{3}{ }^{-} / \mathrm{SO}_{4}{ }^{2-}$ value at a mild pollution level was lower compared to the other three pollution levels. This indicated that the mobile sources contributed more to $\mathrm{PM}_{2.5}$ at the other three pollution levels compared to the stationary sources at a mild pollution level.

The sulfur oxidation ratio (SOR) and nitrogen oxidation ratio (NOR) has also been considered to be indicators for evaluating the secondary transformation processes from gaseous precursors (Yang et al., 2018). In general, SOR and NOR were below 0.10 in the primary pollutant and exceeded 0.10 when the photochemical oxidation of gaseous precursors, $\mathrm{SO}_{2}$ and $\mathrm{NO}_{2}$, would occur in atmosphere environment (Feng et al., 2018). The SOR and NOR had similar values at the four pollution levels, with average values of $0.43 \pm 0.14$ and $0.43 \pm 0.09$, respectively. This indicated that the secondary conversion of $\mathrm{SO}_{2}$ to $\mathrm{SO}_{4}{ }^{2-}$ and $\mathrm{NO}_{2}$ to $\mathrm{NO}_{3}{ }^{-}$occurred during haze episodes. The higher SOR and NOR indicated that the oxidation of gaseous precursors may increase, and more secondary aerosols may be present in the ambient air.

\section{Carbonaceous Species}

The average concentrations of total carbon (TC; which is the sum of OC plus EC) during haze episodes were $27.22 \pm$ $8.22 \mu \mathrm{g} \mathrm{m}^{-3}\left(9.68-47.24 \mu \mathrm{g} \mathrm{m}^{-3}\right)$. The proportion of TC to $\mathrm{PM}_{2.5}$ was $16.31 \pm 2.20 \%$. The concentrations of OC, EC and TC increased as the pollution levels increased (Fig. 5(a)). OC reached the highest and lowest concentrations on Jan. 18 during severe pollution and Jan. 24 during mild pollution, respectively. In contrast, the EC experienced an opposite trend when compared to OC. In addition, the average OC/EC ratio was $3.23 \pm 0.67(1.59-4.60)$ and reached maximum and minimum levels on Jan. 18 and Jan. 17, respectively.

The OC/EC ratios also increased slowly as the pollution levels increased from mild to moderate to heavy to severe levels of pollution $(2.76 \pm 0.71,3.18 \pm 0.57,3.29 \pm 0.69$, and $3.71 \pm 0.69$, respectively). Moreover, the $\mathrm{OC} / \mathrm{EC}$ ratios may indicate the formation of secondary aerosols when it was higher than 2 . The average OC/EC ratios exceeded 2 at the four pollution levels, indicating that secondary aerosols were formed at all four pollution levels. OC was positively correlated with EC $(r=0.76, p<0.05)$ (Fig. 5(b)), indicating they may have the same sources during the sampling period. In addition, low $\mathrm{OC} / \mathrm{EC}$ ratios $(1.5<\mathrm{OC} / \mathrm{EC}<2.5)$ may suggest the contribution of intensive traffic emissions. In contrast, high $\mathrm{OC} / \mathrm{EC}$ ratios $(\mathrm{OC} / \mathrm{EC}>2.5)$ may imply the rapid transformation of SOC precursors, such as VOCs (Pachauri et al., 2013), during the haze episodes (Fig. 5(c)). The average OC/EC ratio was higher at a severe pollution level than that at a heavy pollution level. This indicated that more secondary organic aerosols were produced during period of severe pollution compared to periods of heavy pollution, followed by periods of moderate and mild pollution. The average mass concentrations of organic matter (OM), primary organic carbon and secondary organic carbon were 

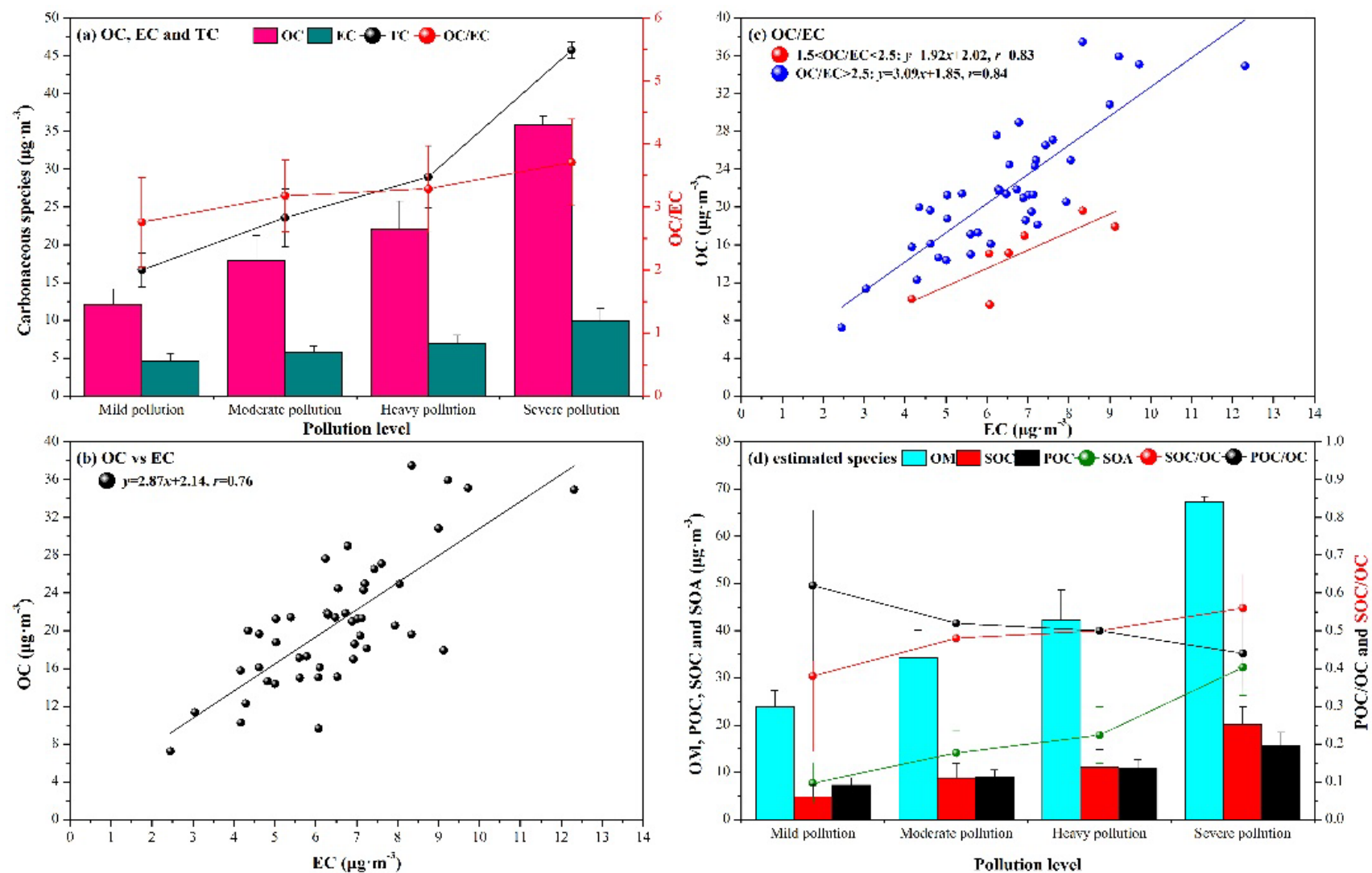

Fig. 5. The variations of carbonaceous species at four pollution levels: (a) OC, EC, and TC; (b) estimated species; (c) OC vs. EC; and (d) OC/EC.

estimated using Eqs. (10)-(12) (Li et al., 2019).

$O M=1.6 \times O C$

$S O C=O C-(O C E C)_{\min } \times E C$

$P O C=O C-S O C$

In this expression, $(O C / E C)_{\min }$ was the minimum value of OC/EC, which was 1.59 in this study. This was consistent with a different study in the cold season (1.60), done by Cesari et al. (2018).

Fig. 5(d) shows the variations in the estimated OM, POC, and SOC at four pollution levels. The average OM concentration was $33.18 \pm 10.86 \mu \mathrm{g} \mathrm{m} \mathrm{m}^{-3}$, ranging from $11.57 \mu \mathrm{g} \mathrm{m}^{-3}$ to $60.01 \mu \mathrm{g} \mathrm{m}^{-3}$. The estimated average mass concentrations of OM, POC and SOC increased as pollution levels increased. This further verifies the aggravation of secondary transformation as discussed above. It was unexpected to have the POC dominate the OC during periods of mild and moderate pollution (62\% and $52 \%$, respectively). In contrast, SOC dominated the OC during periods of severe pollution $(56 \%)$. The proportions of POC and SOC remained at the same level during periods of heavy pollution $(50 \%)$ in Xiangyang.

\section{Trace Elements}

The TE concentrations were $11.24 \pm 2.75,10.85 \pm 4.48$,
$10.71 \pm 2.43$ and $9.60 \pm 3.54 \mu \mathrm{g} \mathrm{m}^{-3}$ at mild, moderate, heavy, and severe pollution levels, respectively. The proportion of TEs to $\mathrm{PM}_{2.5}$ was $6.78 \pm 2.86 \%$. Eleven trace elements, including $\mathrm{As}, \mathrm{Sb}, \mathrm{Al}, \mathrm{Zn}, \mathrm{Si}, \mathrm{Pb}, \mathrm{Co}, \mathrm{Mn}, \mathrm{Ba}, \mathrm{As}$, and $\mathrm{Sn}$, dominated $96.80 \%$ of the mass concentrations of TEs. Fig. 6 shows the variation in the mass concentrations of trace elements at the four pollution levels. The mass concentrations of $\mathrm{Li}, \mathrm{Al}, \mathrm{Mn}, \mathrm{Cu}, \mathrm{Zn}$, Se, Sr, Cd, Sn, Tl and Bi increased as pollution levels intensified, while the mass concentrations of $\mathrm{Co}, \mathrm{Sb}$ and $\mathrm{Th}$ decreased as pollution levels increased. This may be due to variations in emissions from industrial sources or influences from meteorological conditions.

$\mathrm{Pb} / \mathrm{Cd}$ ratios are commonly used to distinguish the sources of metals (Bressi et al., 2014). The results showed that the average $\mathrm{Pb} / \mathrm{Cd}$ ratios at moderate and severe pollution levels (46.42 \pm 14.14 and $38.11 \pm 4.79$, respectively) approached 46 (anthropogenic emissions). This indicated that $\mathrm{Pb}$ and $\mathrm{Cd}$ can likely be attributed to anthropogenic activities at these two pollution levels. In addition, $\mathrm{Pb}$ correlated well with $\mathrm{Cd}$ at times of heavy pollution $(r=0.74, p<0.05)$, indicating they may come from the same sources. V/Ni ratios are generally used to characterize industrial emissions (0.7-1.9) and shipping emissions (2.1-3.1) (Mamane et al., 2008; Bressi et al., 2014). The average $\mathrm{V} / \mathrm{Ni}$ ratio ranged from $0.7-1.9$ at moderate and heavy pollution levels, except for mild and severe pollution levels. This indicated that $\mathrm{V}$ and $\mathrm{Ni}$ can be attributed to industrial processes at moderate and heavy pollution levels. Meanwhile, $\mathrm{V}$ was positively correlated well 


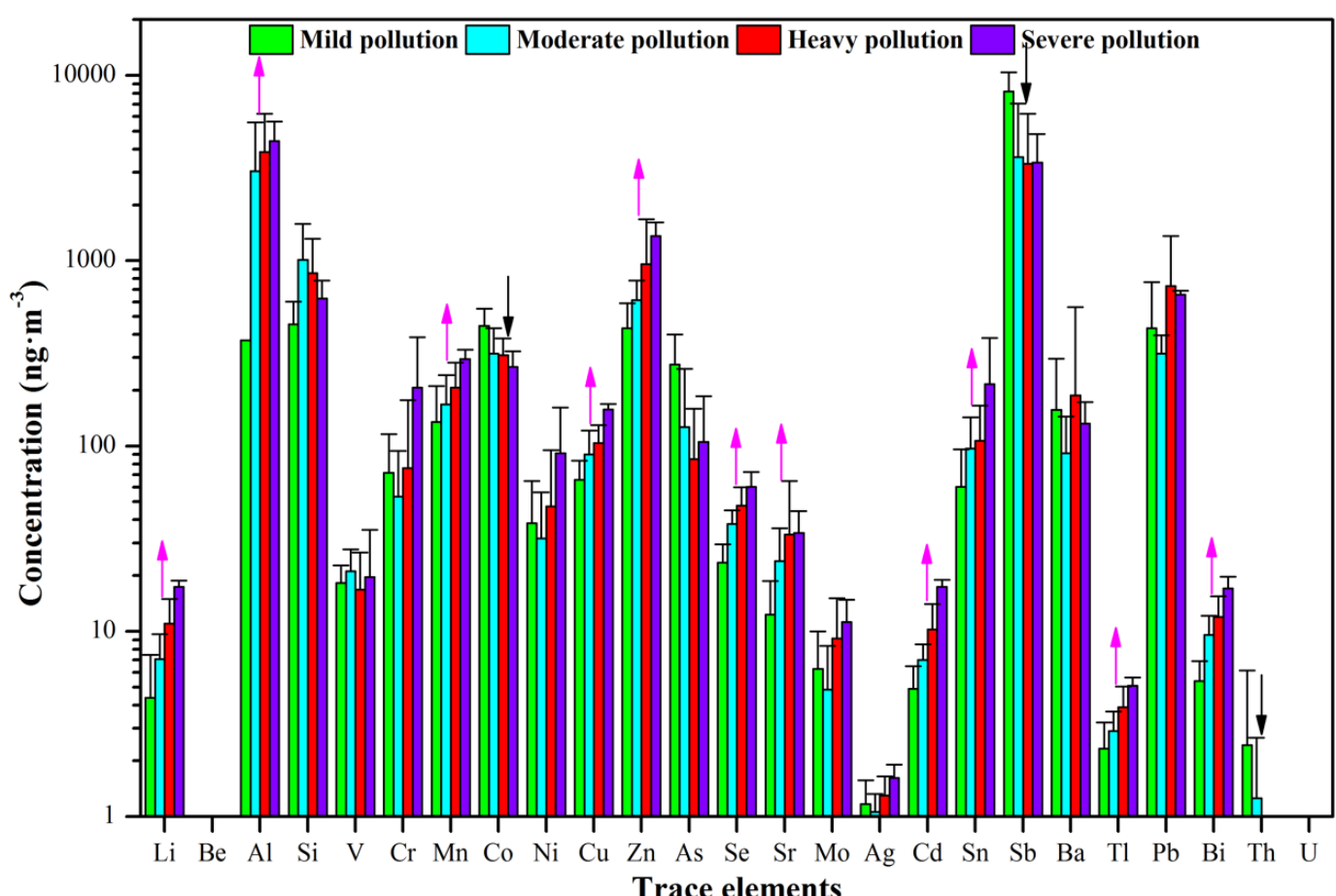

Fig. 6. The concentrations of trace elements at the four pollution levels. (The pink arrow and black arrow represent an uptrend and downtrend, respectively.)

with $\mathrm{Ni}$ at mild and severe pollution levels $(r=0.78,0.97, p$ $<0.05)$. This indicated that $\mathrm{V}$ and $\mathrm{Ni}$ may have the same sources at these two pollution levels.

\section{Chemical Mass Closure}

Chemical mass closure, including mineral dust (MD; i.e., soil, dust, or mineral), trace element oxides (TEOs), OM, EC, SNA, $\mathrm{Cl}^{-}$and unidentified matter (UM), were calculated to better understand the $\mathrm{PM}_{2.5}$ chemical compositions, which were estimated by Eqs. (13)-(16) (Zhang et al., 2013; Kong et al., 2015; Zheng et al., 2019).

$M D=S i \times 2.14+T i \times 1.67+A l \times 1.89+M n \times 1.59+M g$

$\times 1.67+\mathrm{Ca} \times 1.95+\mathrm{Na} \times 1.35+\mathrm{K} \times 1.21+\mathrm{Fe} \times 1.43$

$T E O=[(\mathrm{Sr}+\mathrm{Ba}+\mathrm{Mn}+\mathrm{Co}+\mathrm{Rb}+\mathrm{Ni}+\mathrm{V}) \times 0.5+(\mathrm{Cu}+$ $\mathrm{Zn}+\mathrm{Mo}+\mathrm{Cd}+\mathrm{Sn}+\mathrm{Tl}+\mathrm{Pb}+\mathrm{As}+\mathrm{Cs}) \times 1.0] \times 1.3$

$S N A=\left[\mathrm{SO}_{4} 2^{-}\right]+\left[\mathrm{NO}_{3}{ }^{-}\right]+\left[\mathrm{NH}_{4}{ }^{+}\right]$

$U M=\mathrm{PM}_{2.5}-M D-T E O-O M-E C-S N A-\mathrm{Cl}^{-}$

Figs. 7(a)-7(d) presents the percentage variation of species in $\mathrm{PM}_{2.5}$ at the four different pollution levels. The percentage of SNA in $\mathrm{PM}_{2.5}$ increased with the aggravation of pollution levels, while the percentage of EC and TEOs in $\mathrm{PM}_{2.5}$ decreased as the pollution levels increased. The other species (MD, OM and $\mathrm{Cl}^{-}$) fluctuated with an "up-down" trend at four pollution levels, which may imply changes in the contribution of pollution sources to species. Among them, approximately $80 \%$ of $\mathrm{PM}_{2.5}$ could be explained by SNA and OM during the whole winter haze episode. On average, about $3.45 \%$ of the $\mathrm{PM}_{2.5}$ could not be identified in this study, which indicated that the chemical mass of $\mathrm{PM}_{2.5}$ at each pollution level was balanced within the limits of error.

\section{Contamination Level}

Figs. 8(a)-8(e) show the EF and $\mathrm{I}_{\mathrm{Geo}}$ values of $\mathrm{PM}_{2.5}$-bound metal(loid)s. The EF values for $\mathrm{PM}_{2.5}$-bound metal(loid)s range widely, from 2 to 100,000 in this study. This indicated that most $\mathrm{PM}_{2.5}$-bound metal(loid)s were impacted by both natural and anthropogenic activities. Most metal(loid)s, including $\mathrm{Cr}$, Co, Ni, Cu, Zn, As, Se, Mo, Ag, Cd, Sn, Sb, $\mathrm{Tl}, \mathrm{Pb}$, and $\mathrm{Bi}(\mathrm{EF}>10)$, showed significant anthropogenic emissions, most likely from industrial and vehicular activities. The EF values of $\mathrm{Be}, \mathrm{Th}, \mathrm{U}, \mathrm{Li}, \mathrm{V}, \mathrm{Mn}, \mathrm{Sr}$ and $\mathrm{Ba}$ ranged from 2-10. This indicated that these metal(loid)s were slightly enriched in ambient air and were most likely to be affected both by crustal sources and anthropogenic emissions.

The samples were uncontaminated with $\mathrm{Li}, \mathrm{Be}, \mathrm{Al}, \mathrm{V}, \mathrm{Sr}$, $\mathrm{Ba}$, Th, and $\mathrm{U}\left(\mathrm{I}_{\mathrm{Geo}} \leq 0\right)$. The Mn concentration ranged from uncontaminated to moderately contaminated $\left(0<\mathrm{I}_{\mathrm{Geo}} \leq 1\right)$, and there was moderate $\mathrm{Cr}$ and $\mathrm{Ni}$ contamination $\left(1<\mathrm{I}_{\mathrm{Geo}} \leq\right.$ $2)$. There was heavy contamination with $\mathrm{Cu}$ and $\mathrm{Mo}\left(3<\mathrm{I}_{\mathrm{Geo}}\right.$ $\leq 4)$. As, Ag, and $\mathrm{Tl}$ were present at heavy to extreme contamination levels $\left(4<\mathrm{I}_{\mathrm{Geo}} \leq 5\right)$. Co, $\mathrm{Zn}$, Se, Cd, Sn, Sb, $\mathrm{Pb}$, and $\mathrm{Bi}$ levels signified extreme contamination $\left(\mathrm{I}_{\mathrm{Geo}}>5\right)$. It is likely that $\mathrm{PM}_{2.5}$-bound metal(loid)s, including $\mathrm{Cr}, \mathrm{Ni}$, $\mathrm{Cu}, \mathrm{Mo}, \mathrm{As}, \mathrm{Ag}, \mathrm{Co}, \mathrm{Zn}, \mathrm{Se}, \mathrm{Cd}, \mathrm{Sn}, \mathrm{Sb}, \mathrm{Pb}$ and $\mathrm{Bi}$ concentrations, received significant contributions from anthropologic emissions $\left(\mathrm{I}_{\mathrm{Geo}}>1\right)$. Moreover, the EF and 
$\mathrm{I}_{\mathrm{Geo}}$ values for $\mathrm{PM}_{2.5}$-bound metal(loid)s were strongly positively correlated with a consistent variation trend, confirmed by Izhar et al. (2016). Moreover, the EF and $\mathrm{I}_{\mathrm{Geo}}$ values decreased as the pollution levels increased.

\section{Human Exposure and Health Risk}

Human Exposure Dose

Table 1 presents the ADEDs of $\mathrm{PM}_{2.5}$-bound metal(loid)s during the sampling period for three different exposure

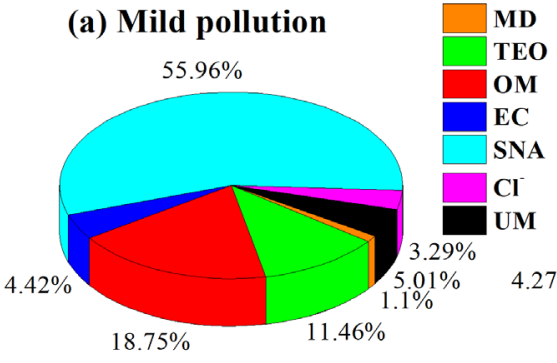

(c) Heavy pollution

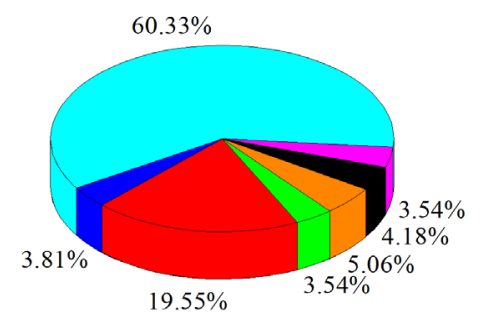

(b) Moderate pollution

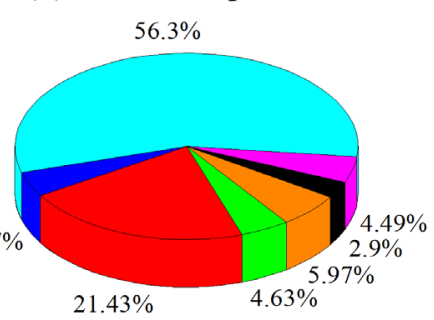

(d) Severe pollution

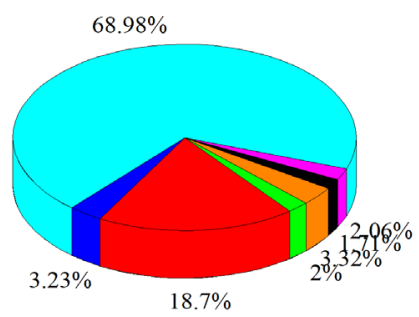

Fig. 7. The chemical mass balance of $\mathrm{PM}_{2.5}$ for (a) mild pollution, (b) moderate pollution, (c) heavy pollution, and (d) severe pollution.
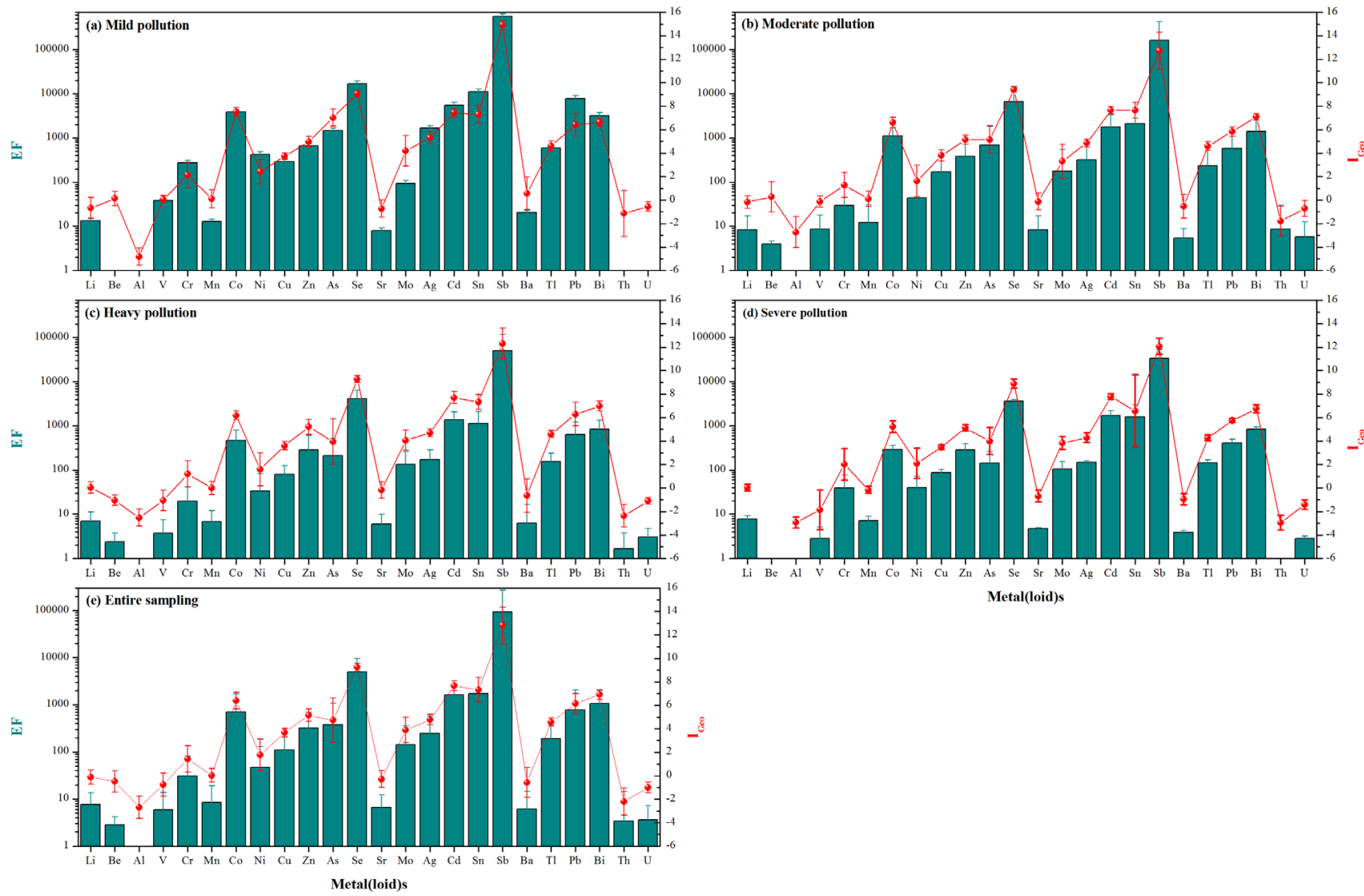

Fig. 8. The EF and $I_{G e o}$ values of $\mathrm{PM}_{2.5}$-bound metal(loid)s for (a) mild pollution, (b) moderate pollution, (c) heavy pollution, (d) severe pollution, and (e) entire sampling. 
pathways: ingestion, inhalation, and dermal contact. The ADEDs of $\mathrm{PM}_{2.5}$-bound metal(loid)s through three different exposure pathways for both children and adults showed the same variation trend $\left(A D E D_{\text {Ing }}>A D E D_{\text {Der }}>A D E D_{\text {Inh }}\right)$. This result was consistent with a study by Izhar et al. (2016). The levels through the ingestion exposure pathway were 1-2 and 3-4 orders of magnitude higher compared to the dermal contact and inhalation exposure pathways, respectively, at the four pollution levels (Table S4). Among all the $\mathrm{PM}_{2.5-}$ bound metal(loid)s, $\mathrm{U}$ and $\mathrm{Sb}$ had the minimum and maximum ADED values $\left(1.56 \times 10^{-3}\right.$ and $\left.3.97 \times 10^{-1}\right)$ for both children and adults through all the three exposure pathways. Moreover, the ADEDs for children through the three exposure pathways were approximately 6-fold higher than for adults. This indicated that children tended to be exposed to more $\mathrm{PM}_{2.5}$-bound metal(loid)s than adults. However, the results were obtained only due to exposure to $\mathrm{PM}_{2.5}$-bound metal(loid)s in this study.

\section{Non-carcinogenic Risk}

Fig. 9(a) provides the non-carcinogenic risks due to exposure to $\mathrm{PM}_{2.5}$-bound metal(loid)s (As, $\mathrm{Cd}, \mathrm{Cr}$ (III), $\mathrm{Co}, \mathrm{Cu}, \mathrm{Mn}$, $\mathrm{Ni}, \mathrm{Zn}, \mathrm{Pb}, \mathrm{Ag}, \mathrm{Al}, \mathrm{Ba}, \mathrm{Mo}, \mathrm{Sb}, \mathrm{Sr}, \mathrm{U}$ and $\mathrm{V}$ ) for children and adults during the sampling period. The HI values ranged from $4.10 \times 10^{-3}-2.64 \times 10^{3}$ and $1.45 \times 10^{-3}-3.03 \times 10^{3}$ for children and adults, respectively, through the three exposure pathways. Among all the $\mathrm{PM}_{2.5}$-bound metal(loid)s, $\mathrm{Sr}$ and $\mathrm{Sb}$ had the minimum and maximum non-carcinogenic risks, respectively, for both children and adults through the three different exposure pathways. The total non-carcinogenic risk was slightly higher for adults $\left(3.07 \times 10^{3}\right)$ compared to children $\left(2.71 \times 10^{3}\right)$. The total non-carcinogenic risks decreased as the pollution levels increased for both children and adults: mild pollution $\left(4.22 \times 10^{3}\right.$ and $\left.4.84 \times 10^{3}\right)>$ moderate pollution $\left(2.49 \times 10^{3}\right.$ and $\left.2.81 \times 10^{3}\right)>$ heavy pollution $\left(1.65 \times 10^{3}\right.$ and $\left.1.86 \times 10^{3}\right)>$ severe pollution $(1.05$ $\times 10^{3}$ and $\left.1.19 \times 10^{3}\right)$.

This outcome may be due to the fact that TE concentrations dropped as the pollution levels increased, consistent with the section "Trace elements," in which As, $\mathrm{Cr}(\mathrm{III})$, and $\mathrm{Pb}$ had greater non-carcinogenic risks on human health among all the metal(loid)s. With the exception of Co for children and $\mathrm{V}$ for adults, the total non-carcinogenic risks of $\mathrm{As}, \mathrm{Cr}(\mathrm{III}), \mathrm{Pb}$ and $\mathrm{Sb}$ were more significant both for children and adults among all the $\mathrm{PM}_{2.5}$-bound metal(loid)s during the winter haze episodes.

\section{Carcinogenic Risk}

Fig. 9(b) presents the carcinogenic risks due to exposure to $\mathrm{PM}_{2.5}$-bound metal(loid)s (As, $\mathrm{Cd}, \mathrm{Co}, \mathrm{Cr}(\mathrm{VI}), \mathrm{Ni}$ and $\mathrm{Pb}$ ) for children and adults during the sampling period. The decreasing order of carcinogenic risks due to exposure to $\mathrm{PM}_{2.5}$-bound metal(loid)s followed similar trends for both children and adults: $\mathrm{As}>\mathrm{Pb}>\mathrm{Cr}(\mathrm{VI})>\mathrm{Co}>\mathrm{Cd}>\mathrm{Ni}$. The $\mathrm{CR}$ values ranged from $7.28 \times 10^{-9}-1.87 \times 10^{-3}$ and $1.64 \times$ $10^{-8}-3.30 \times 10^{-3}$ for children and adults, respectively, through the three different exposure pathways. Among all the $\mathrm{PM}_{2.5}$-bound metal(loid)s, $\mathrm{Ni}$ and As were found to pose the minimum and maximum carcinogenic risks for both children and adults, respectively, through the three different exposure pathways. The total carcinogenic risks were also slightly higher for adults $\left(3.78 \times 10^{-3}\right)$ compared to children $\left(2.99 \times 10^{-3}\right)$.

The total carcinogenic risk decreased as the pollution levels increased for both children and adults: mild pollution $\left(1.64 \times 10^{-1}\right.$ and $\left.2.21 \times 10^{-1}\right)>$ moderate pollution $(2.71 \times$ $10^{-3}$ and $\left.3.77 \times 10^{-3}\right)>$ heavy pollution $\left(2.27 \times 10^{-3}\right.$ and 2.30 $\left.\times 10^{-3}\right)>$ severe pollution $\left(1.48 \times 10^{-3}\right.$ and $\left.1.65 \times 10^{-3}\right)$. This may be due to fact that TE concentrations fell as pollution levels increased, as discussed above in the section "Trace elements." The elements As, $\mathrm{Cr}(\mathrm{VI})$, and $\mathrm{Pb}$ resulted in greater carcinogenic risks to human health among all the

Table 1. The average daily exposure doses $\left(\mathrm{mg} \mathrm{kg}^{-1}\right.$ day $\left.{ }^{-1}\right)$ of $\mathrm{PM}_{2.5}$-bound metal(loid)s for the three different exposure pathways during the sampling period.

\begin{tabular}{|c|c|c|c|c|c|c|c|c|}
\hline \multirow{2}{*}{ Metal(loid)s } & \multicolumn{4}{|c|}{ Children } & \multicolumn{4}{|c|}{ Adults } \\
\hline & $A D E D_{\text {Ing }}$ & $A D E D_{\text {Inh }}$ & $A D E D_{\text {Der }}$ & $A D E D$ & $A D E D_{\text {Ing }}$ & $A D E D_{\text {Inh }}$ & $A D E D_{\text {Der }}$ & $A D E D$ \\
\hline As & $1.26 \mathrm{E}-02$ & $3.52 \mathrm{E}-07$ & $1.32 \mathrm{E}-03$ & $1.39 \mathrm{E}-02$ & $1.67 \mathrm{E}-03$ & $2.45 \mathrm{E}-07$ & $2.85 \mathrm{E}-03$ & $4.52 \mathrm{E}-03$ \\
\hline $\mathrm{Cd}$ & $7.61 \mathrm{E}-04$ & $2.13 \mathrm{E}-08$ & $2.66 \mathrm{E}-06$ & 7.64E-04 & $1.01 \mathrm{E}-04$ & $1.48 \mathrm{E}-08$ & $5.75 \mathrm{E}-06$ & $1.07 \mathrm{E}-04$ \\
\hline $\mathrm{Cr}$ & $5.48 \mathrm{E}-03$ & $1.53 \mathrm{E}-07$ & $1.92 \mathrm{E}-04$ & $5.68 \mathrm{E}-03$ & $6.12 \mathrm{E}-04$ & $9.01 \mathrm{E}-08$ & $3.49 \mathrm{E}-04$ & $9.62 \mathrm{E}-04$ \\
\hline $\mathrm{Co}$ & 3.09E-02 & 8.64E-07 & $1.08 \mathrm{E}-03$ & $3.20 \mathrm{E}-02$ & 4.10E-03 & $6.03 \mathrm{E}-07$ & 2.34E-03 & $6.44 \mathrm{E}-03$ \\
\hline $\mathrm{Cu}$ & 7.76E-03 & 2.17E-07 & $2.72 \mathrm{E}-04$ & 8.04E-03 & 8.32E-04 & $1.22 \mathrm{E}-07$ & 4.74E-04 & $1.31 \mathrm{E}-03$ \\
\hline $\mathrm{Mn}$ & $1.51 \mathrm{E}-02$ & 4.22E-07 & $5.28 \mathrm{E}-04$ & $1.56 \mathrm{E}-02$ & $1.62 \mathrm{E}-03$ & $2.38 \mathrm{E}-07$ & $9.22 \mathrm{E}-04$ & $2.54 \mathrm{E}-03$ \\
\hline $\mathrm{Ni}$ & 3.93E-03 & $1.10 \mathrm{E}-07$ & $1.38 \mathrm{E}-04$ & $4.07 \mathrm{E}-03$ & $5.21 \mathrm{E}-04$ & $7.66 \mathrm{E}-08$ & $2.97 \mathrm{E}-04$ & $8.18 \mathrm{E}-04$ \\
\hline $\mathrm{Zn}$ & $6.22 \mathrm{E}-02$ & $1.74 \mathrm{E}-06$ & $2.18 \mathrm{E}-03$ & $6.44 \mathrm{E}-02$ & $6.67 \mathrm{E}-03$ & $9.81 \mathrm{E}-07$ & $3.80 \mathrm{E}-03$ & $1.05 \mathrm{E}-02$ \\
\hline $\mathrm{Pb}$ & 4.87E-02 & $1.36 \mathrm{E}-06$ & $1.70 \mathrm{E}-03$ & $5.04 \mathrm{E}-02$ & $6.45 \mathrm{E}-03$ & $9.49 \mathrm{E}-07$ & $3.68 \mathrm{E}-03$ & $1.01 \mathrm{E}-02$ \\
\hline $\mathrm{Ag}$ & 9.93E-05 & $2.77 \mathrm{E}-09$ & $3.47 \mathrm{E}-06$ & $1.03 \mathrm{E}-04$ & $1.06 \mathrm{E}-05$ & $1.56 \mathrm{E}-09$ & $6.06 \mathrm{E}-06$ & $1.67 \mathrm{E}-05$ \\
\hline $\mathrm{Al}$ & $2.61 \mathrm{E}-01$ & $7.28 \mathrm{E}-06$ & $9.12 \mathrm{E}-03$ & $2.70 \mathrm{E}-01$ & $2.79 \mathrm{E}-02$ & $4.11 \mathrm{E}-06$ & $1.59 \mathrm{E}-02$ & 4.38E-02 \\
\hline $\mathrm{Ba}$ & $1.12 \mathrm{E}-02$ & $3.12 \mathrm{E}-07$ & $3.91 \mathrm{E}-04$ & $1.16 \mathrm{E}-02$ & $1.20 \mathrm{E}-03$ & $1.76 \mathrm{E}-07$ & $6.83 \mathrm{E}-04$ & $1.88 \mathrm{E}-03$ \\
\hline Mo & $6.09 \mathrm{E}-04$ & $1.70 \mathrm{E}-08$ & $2.13 \mathrm{E}-05$ & $6.30 \mathrm{E}-04$ & $6.52 \mathrm{E}-05$ & $9.59 \mathrm{E}-09$ & $3.72 \mathrm{E}-05$ & $1.02 \mathrm{E}-04$ \\
\hline $\mathrm{Sb}$ & $3.84 \mathrm{E}-01$ & $1.07 \mathrm{E}-05$ & $1.34 \mathrm{E}-02$ & $3.97 \mathrm{E}-01$ & 4.11E-02 & $6.04 \mathrm{E}-06$ & 2.34E-02 & $6.45 \mathrm{E}-02$ \\
\hline $\mathrm{Sr}$ & $2.09 \mathrm{E}-03$ & $5.85 \mathrm{E}-08$ & 7.33E-05 & $2.17 \mathrm{E}-03$ & 2.24E-04 & $3.30 \mathrm{E}-08$ & $1.28 \mathrm{E}-04$ & $3.52 \mathrm{E}-04$ \\
\hline $\mathrm{U}$ & $3.26 \mathrm{E}-05$ & $9.10 \mathrm{E}-10$ & $1.14 \mathrm{E}-06$ & $3.37 \mathrm{E}-05$ & $3.49 \mathrm{E}-06$ & $5.13 \mathrm{E}-10$ & $1.99 \mathrm{E}-06$ & $5.48 \mathrm{E}-06$ \\
\hline $\mathrm{V}$ & $1.50 \mathrm{E}-03$ & 4.20E-08 & $5.27 \mathrm{E}-05$ & $1.56 \mathrm{E}-03$ & $1.61 \mathrm{E}-04$ & $2.37 \mathrm{E}-08$ & $9.19 \mathrm{E}-05$ & $2.53 \mathrm{E}-04$ \\
\hline
\end{tabular}




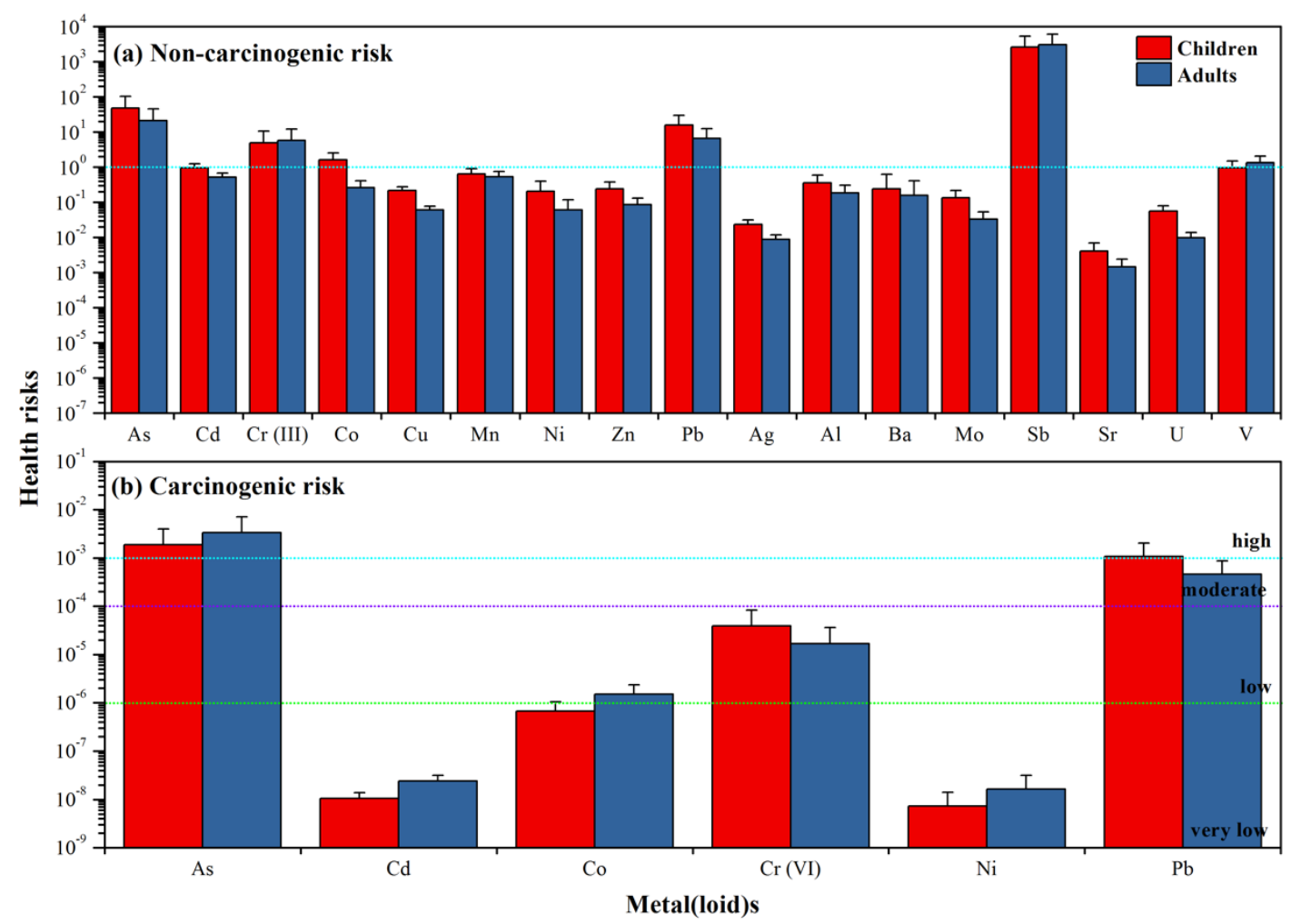

Fig. 9. The human health risks due to exposure to $\mathrm{PM}_{2.5}$-bound metal(loid)s for children and adults: (a) non-carcinogenic risk and (b) carcinogenic risk. (The green, violet, and cyan dash line means carcinogenic risk is very low $\left(\mathrm{CR} \leq 1 \times 10^{-6}\right)$, low $\left(1 \times 10^{-6} \leq \mathrm{CR}<1 \times 10^{-4}\right)$, moderate $\left(1 \times 10^{-4} \leq \mathrm{CR}<1 \times 10^{-3}\right)$, high $\left(1 \times 10^{-3} \leq \mathrm{CR}<1 \times 10^{-1}\right)$ and very high $(\mathrm{CR} \geq$ $\left.1 \times 10^{-1}\right)$ ).

metal(loid)s. Therefore, the non-carcinogenic and carcinogenic risks due to exposure to $\mathrm{PM}_{2.5}$-bound metal(loid)s mainly depended on the concentrations of $\mathrm{PM}_{2.5}$-bound metal(loid)s, and may not have been dependent on the pollution levels.

Carbonaceous species, such as polycyclic aromatic hydrocarbons (PAHs), may impact human health and need to be more fully evaluated in the future. The total noncarcinogenic risks of $\mathrm{As}$ and $\mathrm{Pb}$ were at or above moderate levels for both children and adults. In contrast, the total noncarcinogenic risks of $\mathrm{Cr}(\mathrm{VI}), \mathrm{Co}, \mathrm{Cd}$, and $\mathrm{Ni}$ were below moderate levels for both children and adults among all the $\mathrm{PM}_{2.5}$-bound metal(loid)s. The results indicate that the public and government should implement effective measures to mitigate health risks, including non-carcinogenic and carcinogenic risks due to exposure to these $\mathrm{PM}_{2.5}$-bound metal(loid)s during the winter haze episode in Xiangyang.

\section{CONCLUSIONS}

In this study, we collected forty-eight samples of $\mathrm{PM}_{2.5}$ during a $12 \mathrm{~d}$ winter haze episode (Jan. 13-24, 2018) in Xiangyang of central China in order to determine their characteristics, chemical composition, and associated health risks. On average, the daily concentrations of the $\mathrm{PM}_{2.5}$-bound WSIIs, OC, EC, and TE equaled $111.45 \pm 44.62,20.74 \pm$ $6.79,6.48 \pm 1.79$, and $10.53 \pm 3.84 \mu \mathrm{g} \mathrm{m}^{-3}$, respectively, and that of the total $\mathrm{PM}_{2.5}$ equaled $169.29 \pm 56.98 \mu \mathrm{g} \mathrm{m}^{-3}$, which exceeded the national secondary standard by 2.26 times. The high $\mathrm{PM}_{2.5}$ concentrations during episodes of severe pollution may have been partially due to the arrival of air masses from the NNW-NE, whereas the lower concentrations during periods of less pollution may have been influenced by air masses from the NW-NE or NW-SW.

The OC/EC ratios indicated mixed contributions from intensive traffic emission and secondary formation; hence, the estimated OM, POC, and SOC concentrations predictably increased with the pollution level. However, the POC unexpectedly dominated the $\mathrm{OC}$ during mild and moderate pollution, whereas the SOC dominated it during severe pollution.

Additionally, the contamination levels for $\mathrm{PM}_{2.5}$-bound metal(loid)s evaluated by the enrichment factor (EF) and geo-accumulation index $\left(\mathrm{I}_{\mathrm{Geo}}\right)$ values exhibited a strong positive correlation, but significant anthropogenic emissions also played a role in enriching these $\mathrm{PM}_{2.5}$-bound elements.

Of the $\mathrm{PM}_{2.5}$-bound metal(loid)s, $\mathrm{As}, \mathrm{Cr}, \mathrm{Pb}$, and $\mathrm{Sb}$ pose potential non-carcinogenic risks to both children and adults, and two of these elements, As and $\mathrm{Pb}$, also pose potential carcinogenic risks. The average daily exposure doses via ingestion, dermal contact, and inhalation displayed the same trend for both children and adults, $A D E D_{\text {Ing }}>A D E D_{D e r}>$ $A D E D_{\text {Inh }}$, but the total non-carcinogenic and carcinogenic risks were slightly higher for adults $\left(3.07 \times 10^{3}\right.$ and $3.78 \times$ $10^{-3}$, respectively) than children $\left(2.71 \times 10^{3}\right.$ and $\left.2.99 \times 10^{-3}\right)$ and primarily depended on the concentrations of the metal(loid)s, not the level of pollution. Thus, the public and 
the government should implement efficient measures for mitigating the health risks posed by $\mathrm{PM}_{2.5}$-bound metal(loid)s during winter haze episodes in Xiangyang. Furthermore, carbonaceous species, such as PAHs, may also harm human health and therefore should be more comprehensively investigated in the future.

\section{ACKNOWLEDGMENTS}

This study is supported by the National Key Research and Development Program (2017YFC0212603). The authors are grateful to the staff of the Xiangyang Environmental Protection Monitoring Station for their support to the sampling work.

\section{DISCLAIMER}

The authors declare no competing financial interest.

\section{SUPPLEMENTARY MATERIAL}

Supplementary data associated with this article can be found in the online version at https://doi.org/10.4209/aaqr.2 020.02.0068

\section{REFERENCES}

Akyüz, M. and Çabuk, H. (2009). Meteorological variations of $\mathrm{PM}_{2.5} / \mathrm{PM}_{10}$ concentrations and particle-associated polycyclic aromatic hydrocarbons in the atmospheric environment of Zonguldak, Turkey. J. Hazard. Mater. 170: 13-21. https://doi.org/10.1016/j.jhazmat.2009.05.029

Bressi, M., Sciare, J., Ghersi, V., Mihalopoulos, N., Petit, J.E., Nicolas, J.B., Moukhtar, S., Rosso, A., Féron, A., Bonnaire, N., Poulakis, E. and Theodosi, C. (2014). Sources and geographical origins of fine aerosols in Paris (France). Atmos. Chem. Phys. 14: 8813-8839. https://doi.org/10.5194/acp-14-8813-2014

Cesari, D., De Benedetto, G.E., Bonasoni, P., Busetto, M., Dinoi, A., Merico, E., Chirizzi, D., Cristofanelli, P., Donateo, A., Grasso, F.M., Marinoni, A., Pennetta, A. and Contini, D. (2018). Seasonal variability of $\mathrm{PM}_{2.5}$ and $\mathrm{PM}_{10}$ composition and sources in an urban background site in southern Italy. Sci. Total Environ. 612: 202-213. https://doi.org/10.1016/j.scitotenv.2017.08.230

Cheng, H., Gong, W., Wang, Z., Zhang, F., Wang, X., Lv, X., Liu, J., Fu, X. and Zhang, G. (2014). Ionic composition of submicron particles $\left(\mathrm{PM}_{1.0}\right)$ during the long-lasting haze period in January 2013 in Wuhan, Central China. J. Environ. Sci. 26: 810-817. https://doi.org/10.10 16/S1001-0742(13)60503-3

Dehghani, S., Moore, F., Keshavarzi, B. and Hale, B.A. (2017). Health risk implications of potentially toxic metals in street dust and surface soil of Tehran, Iran. Ecotoxicol. Environ. Saf. 136: 92-103. https://doi.org/10.1016/j.ecoe nv.2016.10.037

Feng, J., Yu, H., Mi, K., Su, X., Li, Y., Li, Q. and Sun, J. (2018). One year study of $\mathrm{PM}_{2.5}$ in Xinxiang City, North China: Seasonal characteristics, climate impact and source.
Ecotoxicol. Environ. Saf. 154: 75-83. https://doi.org/10.1 016/j.ecoenv.2018.01.048

Ferreira-Baptista, L. and De Miguel, E. (2005). Geochemistry and risk assessment of street dust in Luanda, Angola: A tropical urban environment. Atmos. Environ. 39: 4501-4512. https://doi.org/10.1016/j.atmose nv.2005.03.026

Galon-Negru, A.G., Olariu, R.I. and Arsene, C. (2018). Chemical characteristics of size-resolved atmospheric aerosols in Iasi, north-eastern Romania: nitrogencontaining inorganic compounds control aerosol chemistry in the area. Atmos. Chem. Phys. 18: 58795904. https://doi.org/10.5194/acp-18-5879-2018

Gao, M., Guttikunda, S.K., Carmichael, G.R., Wang, Y., Liu, Z., Stanier, C.O., Saide, P.E. and Yu, M. (2015). Health impacts and economic losses assessment of the 2013 severe haze event in Beijing Area. Sci. Total Environ. 511: 553-561. https://doi.org/10.1016/j.scitotenv.2015.0 1.005

Hu, X., Zhang, Y., Ding, Z., Wang, T., Lian, H., Sun, Y. and $\mathrm{Wu}$, J. (2012). Bioaccessibility and health risk of Arsenic and heavy metals $(\mathrm{Cd}, \mathrm{Co}, \mathrm{Cr}, \mathrm{Cu}, \mathrm{Ni}, \mathrm{Pb}, \mathrm{Zn}$ and $\mathrm{Mn})$ in TSP and $\mathrm{PM}_{2.5}$ in Nanjing, China. Atmos. Environ. 57: 146-152. https://doi.org/10.1016/j.atmosenv.2012.04.056

Huang, R.J., Zhang, Y., Bozzetti, C., Ho, K.F., Cao, J.J., Han, Y., Daellenbach, K.R., Slowik, J.G., Platt, S.M., Canonaco, F., Zotter, P., Wolf, R., Pieber, S.M., Bruns, E.A., Crippa, M., Ciarelli, G., Piazzalunga, A., Schwikowski, M., Abbaszade, G., ... Prévôt, A.S.H. (2014). High secondary aerosol contribution to particulate pollution during haze events in China. Nature 514: 218-222. https://doi.org/10. 1038/nature 13774

IARC (International Agency for Research on Cancer) (2020). Agents Classified by the IARC Monographs, Volumes 1-125. International Agency for Research on Cancer.

Izhar, S., Goel, A., Chakraborty, A. and Gupta, T. (2016). Annual trends in occurrence of submicron particles in ambient air and health risk posed by particle bound metals. Chemosphere 146: 582-590. https://doi.org/10.1016/j.ch emosphere.2015.12.039

Khanna, I., Khare, M., Gargava, P. and Khan, A.A. (2018). Effect of $\mathrm{PM}_{2.5}$ chemical constituents on atmospheric visibility impairment. J. Air Waste Manage. Assoc. 68: 430-437. https://doi.org/10.1080/10962247.2018.1425772

Kong, S.F., Li, L., Li, X.X., Yin, Y., Chen, K., Liu, D.T., Yuan, L., Zhang, Y.J., Shan, Y.P. and Ji, Y.Q. (2015). The impacts of firework burning at the Chinese Spring Festival on air quality: insights of tracers, source evolution and aging processes. Atmos. Chem. Phys. 15: 2167-2184. https://doi.org/10.5194/acp-15-2167-2015

Li, H., Qian, X., Hu, W., Wang, Y. and Gao, H. (2013). Chemical speciation and human health risk of trace metals in urban street dusts from a metropolitan city, Nanjing, SE China. Sci. Total Environ. 456-457: 212-221. https://doi.org/10.1016/j.scitotenv.2013.03.094

Li, N., Han, W., Wei, X., Shen, M. and Sun, S. (2019). Chemical characteristics and human health assessment of $\mathrm{PM}_{1}$ during the Chinese Spring Festival in Changchun, 
Northeast China. Atmos. Pollut. Res. 10: 1823-1831. https://doi.org/10.1016/j.apr.2019.07.014

Liu, H., Tian, H., Zhang, K., Liu, S., Cheng, K., Yin, S., Liu, Y., Liu, X., Wu, Y., Liu, W., Bai, X., Wang, Y., Shao, P., Luo, L., Lin, S., Chen, J. and Liu, X. (2019). Seasonal variation, formation mechanisms and potential sources of $\mathrm{PM}_{2.5}$ in two typical cities in the Central Plains Urban Agglomeration, China. Sci. Total Environ. 657: 657-670. https://doi.org/10.1016/j.scitotenv.2018.12.068

Liu, J., Li, J., Liu, D., Ding, P., Shen, C., Mo, Y., Wang, X., Luo, C., Cheng, Z., Szidat, S., Zhang, Y., Chen, Y. and Zhang, G. (2016a). Source apportionment and dynamic changes of carbonaceous aerosols during the haze bloomdecay process in China based on radiocarbon and organic molecular tracers. Atmos. Chem. Phys. 16: 2985-2996. https://doi.org/10.5194/acp-16-2985-2016

Liu, J., Li, J., Vonwiller, M., Liu, D., Cheng, H., Shen, K., Salazar, G., Agrios, K., Zhang, Y., He, Q., Ding, X., Zhong, G., Wang, X., Szidat, S. and Zhang, G. (2016b). The importance of non-fossil sources in carbonaceous aerosols in a megacity of central China during the 2013 winter haze episode: A source apportionment constrained by radiocarbon and organic tracers. Atmos. Environ. 144: 60-68. https://doi.org/10.1016/j.atmosenv.2016.08.068

Lyu, X.P., Wang, Z.W., Cheng, H.R., Zhang, F., Zhang, G., Wang, X.M., Ling, Z.H. and Wang, N. (2015). Chemical characteristics of submicron particulates $\left(\mathrm{PM}_{1.0}\right)$ in Wuhan, central China. Atmos. Res. 161-162: 169-178. https://doi.org/10.1016/j.atmosres.2015.04.009

Mamane, Y., Perrino, C., Yossef, O. and Catrambone, M. (2008). Source characterization of fine and coarse particles at the East Mediterranean coast. Atmos. Environ. 42: 61146130. https://doi.org/10.1016/j.atmosenv.2008.02.045

Massey, D.D., Kulshrestha, A. and Taneja, A. (2013). Particulate matter concentrations and their related metal toxicity in rural residential environment of semi-arid region of India. Atmos. Environ. 67: 278-286. https://doi.org/10.1016/j.atmosenv.2012.11.002

Modaihsh, A.S., Al-Barakah, F.N., Nadeem, M.E.A. and Mahjoub, M.O. (2015). Spatial and temporal variations of the particulate matter in Riyadh City, Saudi Arabia. $J$. Environ. Prot. Ecol. 6: 1293-1307. https://doi.org/10.42 36/jep.2015.611113

Pachauri, T., Satsangi, A., Singla, V., Lakhani, A. and Kumari, K.M. (2013). Characteristics and sources of carbonaceous aerosols in $\mathrm{PM}_{2.5}$ during wintertime in Agra, India. Aerosol Air Qual. Res. 13: 977-991. https://doi.org/10.4209/aaqr.2012.10.0263

Qu, Y., Gao, T. and Yang, C. (2019). Elemental characterization and source identification of the near-road $\mathrm{PM}_{2.5}$ using EDXRF in Chengdu, China. X-Ray Spectrom. 48: 232-241. https://doi.org/10.1002/xrs.3028

Roy, D., Singh, G. and Seo, Y. (2019). Carcinogenic and non-carcinogenic risks from $\mathrm{PM}_{10^{-}}$and $\mathrm{PM}_{2.5}$-Bound metals in a critically polluted coal mining area. Atmos. Pollut. Res. 10: 1964-1975. https://doi.org/10.1016/j.apr. 2019.09.002

Shen, R., Liu, Z., Chen, X., Wang, Y., Wang, L., Liu, Y. and Li, X. (2019). Atmospheric levels, variations, sources and health risk of $\mathrm{PM}_{2.5}$-bound polycyclic aromatic hydrocarbons during winter over the North China Plain. Sci. Total Environ. 655: 581-590. https://doi.org/10.1016/ j.scitotenv.2018.11.220

U.S. EPA (2011). Exposure factors handbook: 2011 edition. U.S. Environmental Protection Agency, Washington, DC, EPA/600/R-09/052F.

Wang, S., Yin, S., Zhang, R., Yang, L., Zhao, Q., Zhang, L., Yan, Q., Jiang, N. and Tang, X. (2019). Insight into the formation of secondary inorganic aerosol based on hightime-resolution data during haze episodes and snowfall periods in Zhengzhou, China. Sci. Total Environ. 660: 47-56. https://doi.org/10.1016/j.scitotenv.2018.12.465

Wang, Y., Zhuang, G., Tang, A., Yuan, H., Sun, Y., Chen, S. and Zheng, A. (2005). The ion chemistry and the source of $\mathrm{PM}_{2.5}$ aerosol in Beijing. Atmos. Environ. 39: 37713784. https://doi.org/10.1016/j.atmosenv.2005.03.013

Wei, X., Liu, M., Yang, J., Du, W., Sun, X., Huang, Y., Zhang, X., Khalil, S.K., Luo, D. and Zhou, Y. (2019). Characterization of $\mathrm{PM}_{2.5}$-bound PAHs and carbonaceous aerosols during three-month severe haze episode in Shanghai, China: Chemical composition, source apportionment and long-range transportation Atmos. Environ. 203: 1-9. https://doi.org/10.1016/j.atmosenv.2 019.01 .046

Xie, Y., Liu, Z., Wen, T., Huang, X., Liu, J., Tang, G., Yang, Y., Li, X., Shen, R., Hu, B. and Wang, Y. (2019). Characteristics of chemical composition and seasonal variations of $\mathrm{PM}_{2.5}$ in Shijiazhuang, China: Impact of primary emissions and secondary formation. Sci. Total Environ. 677: 215-229. https://doi.org/10.1016/j.scitoten v.2019.04.300

Xie, Z., Qin, Y., Zhang, L. and Zhang, R. (2018). Death effects assessment of $\mathrm{PM}_{2.5}$ pollution in China. Pol. $J$. Environ. Stud. 27: 1813-1821. https://doi.org/10.15244/ pjoes $/ 77077$

Xue, H., Liu, G., Zhang, H., Hu, R. and Wang, X. (2019a). Similarities and differences in $\mathrm{PM}_{10}$ and $\mathrm{PM}_{2.5}$ concentrations, chemical compositions and sources in Hefei City, China. Chemosphere 220: 760-765. https://doi.org/10.1016/j.chemosphere.2018.12.123

Xue, H., Liu, G., Zhang, H., Hu, R. and Wang, X. (2019b). Elemental composition, morphology and sources of fine particulates $\left(\mathrm{PM}_{2.5}\right)$ in Hefei city, China. Aerosol Air Qual. Res. 19: 1688-1696. https://doi.org/10.4209/aaqr.2 018.09.0341

Yang, S., Ma, Y.L., Duan, F.K., He, K.B., Wang, L.T., Wei, Z., Zhu, L.D., Ma, T., Li, H. and Ye, S.Q. (2018). Characteristics and formation of typical winter haze in Handan, one of the most polluted cities in China. Sci. Total Environ. 613-614: 1367-1375. https://doi.org/10.1 016/j.scitotenv.2017.08.033

Yin, L., Niu, Z., Chen, X., Chen, J., Zhang, F. and Xu, L. (2014). Characteristics of water-soluble inorganic ions in $\mathrm{PM}_{2.5}$ and $\mathrm{PM}_{2.5-10}$ in the coastal urban agglomeration along the Western Taiwan Strait Region, China. Environ. Sci. Pollut. Res. 21: 5141-5156. https://doi.org/10.1007/s 11356-013-2134-7

$\mathrm{Yu}$, J.Z., Xu, J. and Yang, H. (2002). Charring 
characteristics of atmospheric organic particulate matter in thermal analysis. Environ. Sci. Technol. 36: 754-761. https://doi.org/10.1021/es015540q

Zhang, F., Cheng, H.R., Wang, Z.W., Lv, X.P., Zhu, Z.M., Zhang, G. and Wang, X.M. (2014). Fine particles ( $\left.\mathrm{PM}_{2.5}\right)$ at a CAWNET background site in Central China: Chemical compositions, seasonal variations and regional pollution events. Atmos. Environ. 86: 193-202. https://doi.org/10.1016/j.atmosenv.2013.12.008

Zhang, F., Wang, Z.W., Cheng, H.R., Lv, X.P., Gong, W., Wang, X.M. and Zhang, G. (2015). Seasonal variations and chemical characteristics of $\mathrm{PM}_{2.5}$ in Wuhan, Central China. Sci. Total Environ. 518-519: 97-105. https://doi.org/10.1016/j.scitotenv.2015.02.054

Zhang, R., Jing, J., Tao, J., Hsu, S.C., Wang, G., Cao, J., Lee, C.S.L., Zhu, L., Chen, Z., Zhao, Y. and Shen, Z. (2013). Chemical characterization and source apportionment of $\mathrm{PM}_{2.5}$ in Beijing: Seasonal perspective. Atmos. Chem. Phys. 13: 7053-7074. https://doi.org/10.5194/acp-13-7053-2013

Zhang, X., Zhang, K., Lv, W., Liu, B., Aikawa, M. and Wang, J. (2019). Characteristics and risk assessments of heavy metals in fine and coarse particles in an industrial area of central China. Ecotox. Environ. Safe. 179: 1-8. https://doi.org/10.1016/j.ecoenv.2019.04.024

Zheng, H., Kong, S., Yan, Q., Wu, F., Cheng, Y., Zheng, S., Wu, J., Yang, G., Zheng, M., Tang, L., Yin, Y., Chen, K., Zhao, T., Liu, D., Li, S., Qi, S., Zhao, D., Zhang, T., Ruan, J. and Huang, M. (2019). The impacts of pollution control measures on $\mathrm{PM}_{2.5}$ reduction: Insights of chemical composition, source variation and health risk. Atmos. Environ. 197: 103-117. https://doi.org/10.1016/j.atmose nv.2018.10.023

Zhong, S., Zhang, L., Jiang, X. and Gao, P. (2019). Comparison of chemical composition and airborne bacterial community structure in $\mathrm{PM}_{2.5}$ during haze and non-haze days in the winter in Guilin, China. Sci. Total Environ. 655: 202-210. https://doi.org/10.1016/j.scitoten v.2018.11.268

Received for review, February 20, 2020

Revised, June 1, 2020

Accepted, June 2, 2020 